Trinity University

Digital Commons @ Trinity

Sociology \& Anthropology Faculty Research

Sociology and Anthropology Department

$1-2000$

\title{
Wetland Manipulation in the Yalahau Region of the Northern Maya Lowlands
}

Scott L. Fedick

Bethany A. Morrison

B. J. Andersen

S. Boucher

J. C. Acosta

See next page for additional authors

Follow this and additional works at: https://digitalcommons.trinity.edu/socanthro_faculty

Part of the Anthropology Commons, and the Sociology Commons

\section{Repository Citation}

Fedick, S. L., Morrison, B. A., Andersen, B. J., Boucher, S., Acosta, J. C., \& Mathews, J. P. (2000). Wetland manipulation in the Yalahau region of the northern Maya lowlands. Journal of Field Archaeology, 27(2), 131-152. doi: 10.1179/jfa.2000.27.2.131

This Article is brought to you for free and open access by the Sociology and Anthropology Department at Digital Commons @ Trinity. It has been accepted for inclusion in Sociology \& Anthropology Faculty Research by an authorized administrator of Digital Commons @ Trinity. For more information, please contact jcostanz@trinity.edu. 


\section{Authors}

Scott L. Fedick, Bethany A. Morrison, B. J. Andersen, S. Boucher, J. C. Acosta, and Jennifer P. Mathews 


\title{
Wetland Manipulation in the Yalahau Region of the Northern Maya Lowlands
}

\author{
Scott L. Fedick \\ Bethany A. Morrison \\ University of California \\ Riverside, California \\ Bente Juhl Andersen \\ University of Copenhagen \\ Copenhagen, Denmark \\ Sylviane Boucher \\ Instituto Nacional de Antropología e Historia, CRY-Mérida \\ Mérida, Yucatán, México
}

Jorge Ceja Acosta

Universidad Veracruzana

Xalapa, Veracruz, México

Jennifer P. Mathews

Trinity University

San Antonio, Texas

Manipulation of wetlands for agricultural purposes by the ancient Maya of southern Mexico and Central America has been a subject of much research and debate since the 1970s. Evidence for wetland cultivation systems, in the form of drained or channelized fields, and raised planting platforms, has been restricted primarily to the southern Maya Lowlands. New research in the Yalabau region of Quintana Roo, Mexico, has recorded evidence for wetland manipulation in the far northern lowlands, in the form of rock alignments that apparently functioned to control water movement and soil accumulation in seasonally inundated areas. Nearby ancient settlements date primarily to the Late Preclassic period (ca. 100 B.C. to A.C. 350), and this age is tentatively attributed to wetland management in the area.

\section{Introduction}

Prior to the 1970s, ancient Maya subsistence was assumed to have been based on swidden (slash-and-burn) cultivation of maize within a tropical forest environment that was rather hostile and agriculturally limited (Fedick 1996; Turner 1978). Expanding settlement pattern studies forced a reassessment of the "swidden thesis" as regional population estimates for the Classic period (ca. A.c. 250-900) soared beyond the accepted carrying capacity of slash-and-burn agriculture. A new era of Maya subsistence studies opened in 1968 with the discovery by geographer Alfred Siemens of patterned ground in the wetlands of
Campeche, Mexico. Joint investigation of these and other features in the early 1970s by Siemens and archaeologist Dennis Puleston produced the first evidence that the ancient Maya had modified and managed wetlands for intensive agriculture (Pohl 1990; Siemens and Puleston 1972). Subsequent studies by several researchers produced tantalizing, though often controversial, evidence that labor-intensive systems of wetland cultivation had been widespread in the southern Maya Lowlands, particularly during the Late Classic period when regional population levels were generally at their peak (e.g., Adams, Brown, and Culbert 1981; see also Turner 1990). Others tempered these 


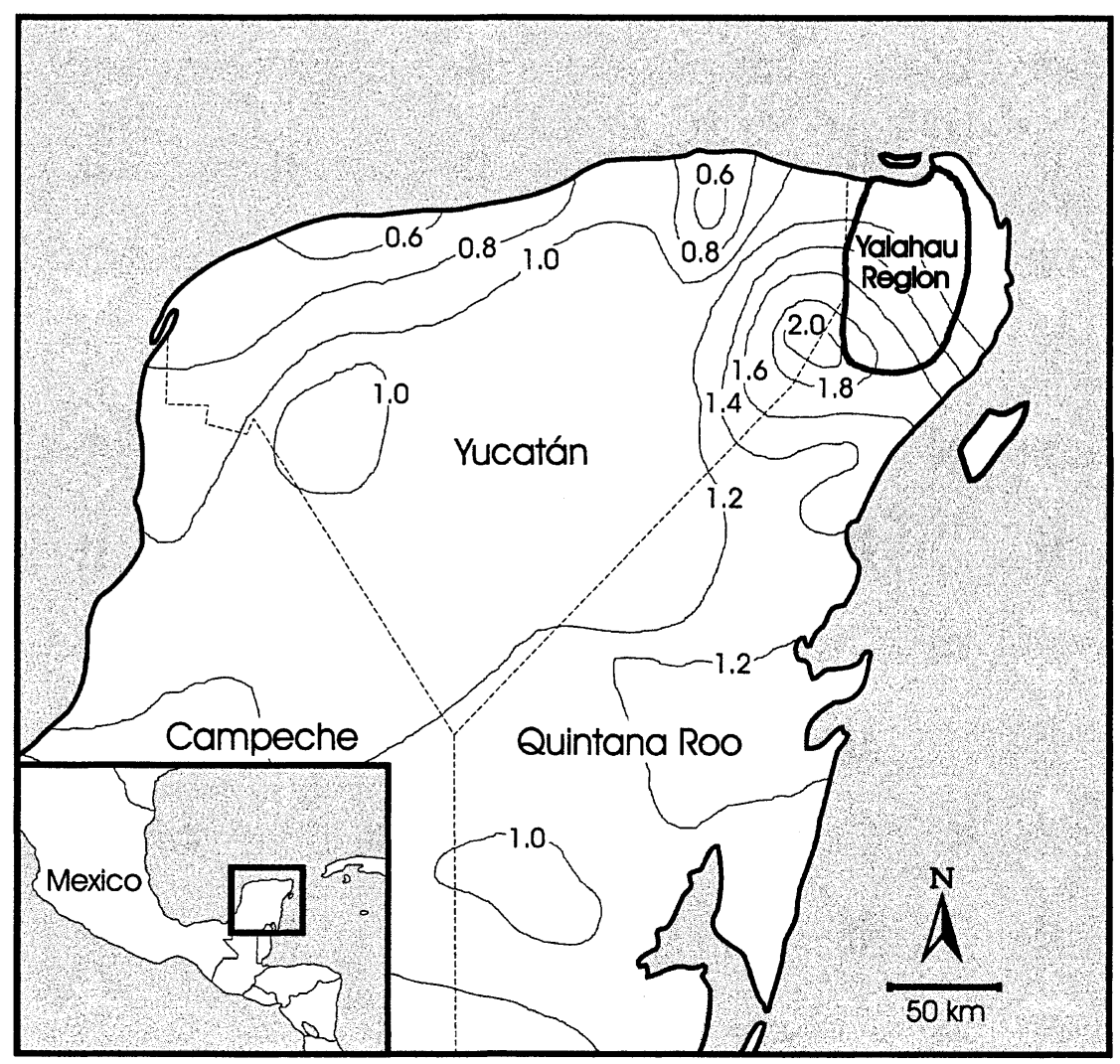

Figure I. The Yucatán Peninsula of Mexico with mean annual rainfall $(\mathrm{m})$ and the location of the Yalahau region.

claims, recognizing the importance of wetland cultivation, but suggesting that ancient use of wetlands was much more restricted in geographic extent, involved less laborintensive cultivation techniques, and had been practiced primarily in karstic riverine floodplains during the Preclassic period when regional water-table levels were lower (Pohl et al. 1996; Pope and Dahlin 1989, 1993).

Current research and debates concerning wetland cultivation in the Maya Lowlands cover a number of interrelated issues: 1) the expanse of wetland cultivation at any given time; 2) the types of wetland ecosystems that were modified; 3 ) the time periods in which wetlands were put to use; 4) the labor required to initiate and maintain a particular wetland cultivation system; 5) the crops or other resources that were produced by a wetland cultivation system; 6) the economic, social, or political circumstances that fostered the development or decline of wetland cultivation; and 7) environmental changes, human induced or "natural" that may have affected wetland cultivation systems. The present contribution focuses on a previously uninvestigated wetland zone located in the Yalahau region of the northern Maya Lowlands (FIG. I), and describes a sys- tem of constructed features that differs from other reported forms of wetland management. A discussion of these findings places them within the context of current research issues of wetland management by the ancient Maya.

\section{Defining the Yalahau Region}

The Yucatán Peninsula is part of a greater geographical unit known as the tropical lowlands of Middle America (West 1964: 370). Tracing the limestone platform of the peninsula from south to north, one finds a general decrease in elevation, topographic relief, forest canopy height, and annual rainfall. In the southern lowlands, south of approximately $19^{\circ} \mathrm{N}$ latitude, several major river systems drain to the eastern and western margins of the peninsula. Surface water is scarce in the interior of the southern lowlands, where the porous karstic geology allows rainwater to move quickly into caves and subsurface rivers, and the water table is generally far deeper than could be reached by hand-dug wells.

The limestone shelf of the northern lowlands is relatively flat; elevations rarely rise higher than $20 \mathrm{~m}$ above mean sea level, with the exception of the Puuc Hills in northern 
Campeche and SE Yucatán. In the northern lowlands there are virtually no surface rivers, and the fresh-water aquifer floats on top of a regional saltwater intrusion (Back and Hanshaw 1970). The principal natural sources of fresh water in the northern lowlands are natural wells or cenotes (karstic sink holes) and occasional small lakes associated with fault systems. The lower elevation of the northern lowlands allows access to the water table in much of the area, where wells can be dug with relative ease through the soft limestone bedrock (Winzler and Fedick 1995). Soils are rich, yet very thin, with vast areas of exposed bedrock mantled with only a skeletal covering of earth. Vegetation of the northern lowlands is medium to low semi-deciduous forest, decreasing to nearly desert-like low scrub-forest in the extreme NW.

The NE corner of the Yucatán Peninsula stands in sharp contrast to the general environmental characteristics of the northern Maya Lowlands. Northern Quintana Roo receives significantly more rain than the rest of the northern lowlands, with an average annual precipitation of up to 1500-2000 mm, an amount comparable to much of the southern lowlands (FIG. I; Isphording 1975: 244; Wilson 1980: 23-25). The abundant rainfall of northern Quintana Roo has contributed to the formation of a series of elongated karst depressions, or solution features, that apparently follow an underlying $\mathrm{N}-\mathrm{S}$ oriented fault system (Tulaczyk 1993: 55-111). This lineament system of depressions and aligned swales is referred to geologically as the Holbox fracture zone, as first defined by geologist A. E. Weidie (1982; see also Tulaczyk 1993; Tulaczyk et al. 1993; Weidie 1985). The elongated depressions support a series of fresh-water wetlands that were apparently formed when the descending karst solution features met the water table (FIG. 2). Consequently, the depth of water and hydro period (duration of flooding) of the wetlands is related to shifts in groundwater levels as well as seasonal rainfall accumulation (Tulaczyk 1993: 112-131).

The Holbox fracture zone extends in well-developed form about $50 \mathrm{~km}$ from the north coast to the south, and is approximately $40 \mathrm{~km}$ wide. The total area of wetlands within this zone covers about $134 \mathrm{sq} \mathrm{km} \mathrm{(FIG.} \mathrm{2).} \mathrm{Analysis}$ of remote sensing data indicates that a less-pronounced section of the Holbox fracture zone extends an additional $50 \mathrm{~km}$ to the south, terminating just north of the ancient center of Cobá (Southworth 1985). We refer to the northern half of the Holbox fracture zone, where wetlands predominate, as the Yalahau region (Fedick and Taube 1995; see also Dunning et al. 1998).

The varied topography of the Yalahau region results in a complex mosaic of soil resources and vegetation zones. Elevated areas of good to excessive drainage are character- ized by surface lithosols with patches of deeper, more productive, rendzina soils. Soils found within the inundated zones of the shallow wetlands are mainly peaty deposits overlying a thin mantle of silty clay, with limestone bedrock at depths rarely exceeding $40 \mathrm{~cm}$. Environmental zones include seasonal to perennial wetlands, well-drained upland areas dominated by semi-deciduous tropical forest reaching a canopy height of about $15 \mathrm{~m}$, and lower forests of secondary growth resulting as an aftermath of hurricanes and the consequential fires that are so frequent in northern Quintana Roo (Konrad 1985; Wilson 1980: 2l-23).

\section{Previous Archaeological Research}

Investigations of ancient Maya use of wetlands for subsistence production have previously been restricted to the southern lowlands, where various forms of wetlands cover about 40 percent of the terrain (for a review of ancient water management in the Maya Lowlands, see Harrison 1993; Matheny 1978; Scarborough 1993, 1994). In contrast, since wetlands are rare in the northern lowlands, being primarily restricted to coastal brackish-water zones, and to the fresh-water wetlands of the Yalahau region, little work has been done here. There have been a few scattered reports of features within the northern coastal wetlands that have been described as isolated linear depressions or channels. These linear features are visible on aerial photographs and have generally been interpreted as abandoned transportation canals of either prehistoric or historical origin (López Ornat 1983; Matheny 1976, 1978; Millet Cámara 1984).

Estuarine lagoons and swamps along the northern and Nw coast of the Yucatán Peninsula support salt-making activities that have been conducted since pre-Hispanic times (Andrews 1983). These salt works consist of constructed rectilinear enclosures, or pans, where salt water is trapped at the beginning of the dry season and evaporates to form thick deposits of salt which are then harvested (Andrews 1983: 22-25). Archaeological evidence of salt making along the coast of the peninsula may extend back as early as the early phase of the Late Preclassic period (ca. 300-50 B.C.), with evidence for ancient salt pans surviving since the Early Classic period (ca. A.c. 300-600; Andrews 1983: 30-31). Anthony Andrews (1983: 41-42) has identified salt pans on the southern coast of Holbox Island (FIG. 2), off the north coast of the Yalahau region, that apparently date to recent times.

Analysis and interpretation of satellite imagery by Charles Duller (1990) has identified patterned ground in coastal wetlands of the Cabo Catoche area (FIG. 2), just NE of the Yalahau region, and suggests these still uninvestigat- 


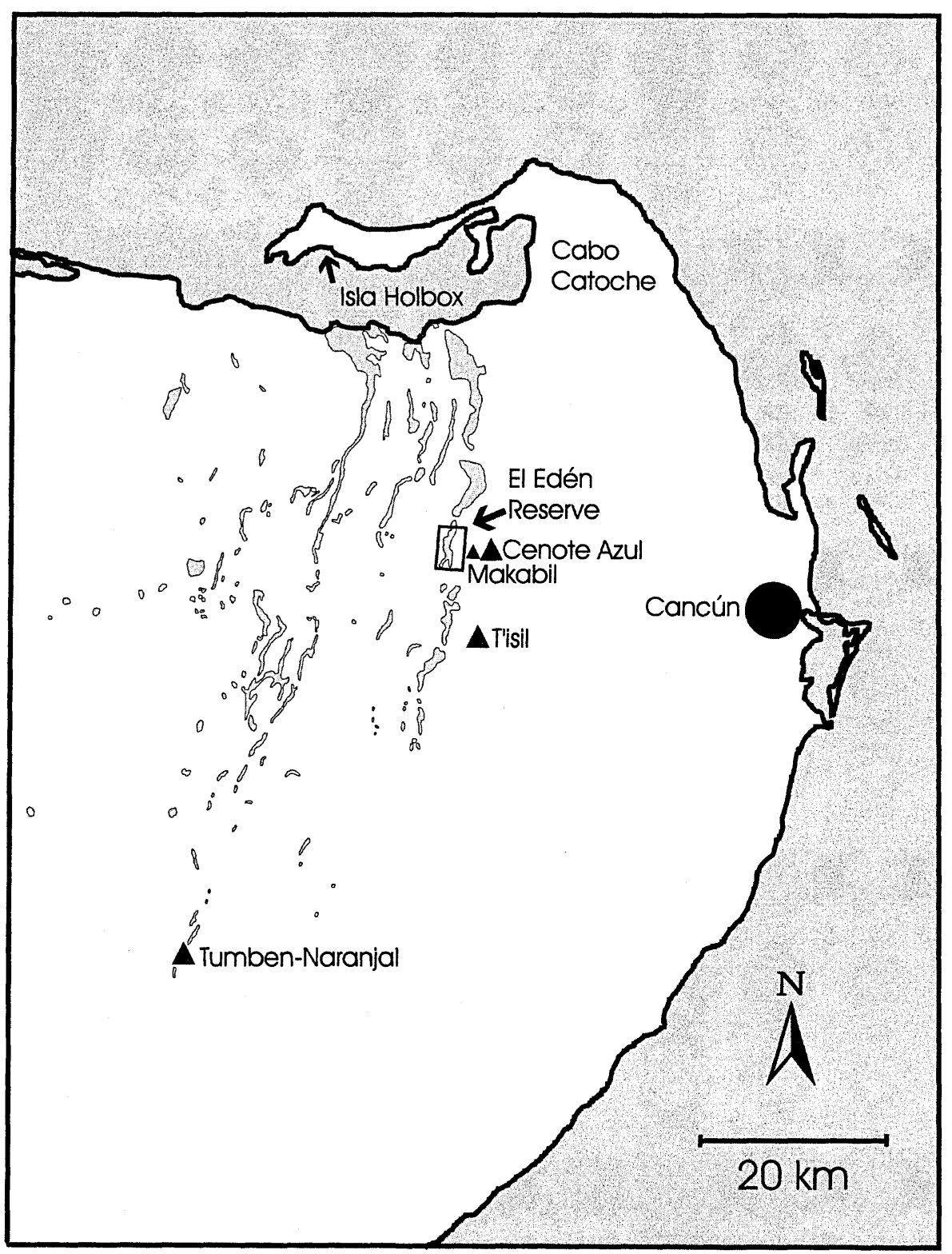

Figure 2. Wetlands of the Yalahau region and location of places mentioned in the text.

ed patterns may represent ancient canals and raised-field complexes.

Prior to the Yalahau Regional Human Ecology Project, little archaeological research had been conducted within the region (Escalona Ramos 1946; Sanders 1955, 1960; see Andrews 1985 for a recent summary of research in northern Quintana Roo). The Project was established in 1993 to investigate ancient Maya political organization, settlement patterns, and land use within the wetland environment of northern Quintana Roo, and to place culture change within this area into the context of Maya regional development (Fedick and Taube 1995, Fedick and Taube eds. 1995). The 1993 field investigations focused on the major center of Tumben-Naranjal (FIG. 2), mapping the large structures that form the core of the site, and documenting the megalithic-style architecture that characterizes the center (Fedick and Taube 1995; Mathews 1995, 1998; Taube 1995). The megalithic style was previously known from sites such as Aké and Izamal, and was generally thought to be restricted to the NW portion of the Yucatán Peninsula sometime during the Late Preclassic and Early Classic periods (ca. 300 B.C.-A.c. 550) (Andrews IV and Stuart 1975: 80; Roys and Shook 1966: 49-50; Sidrys 1978: 157; Velázquez Morlet et al. 1991: 61; Webster 
1979: 156-157; chronology follows Robles Castellanos 1990: table 1). The 1993 season also produced evidence for the Postclassic reuse of earlier monumental structures at Tumben-Naranjal (Lorenzen 1995, 1999), recorded settlement patterns associated with the site and the adjacent wetland and other wetlands in the region (Fedick and Hovey 1995; see also Fedick 1998), investigated ancient use of wells in the area (Winzler and Fedick 1995), mapped numerous ancient roadways and other sites of the region (Fedick, Reid, and Mathews 1995; Mathews 1998; Reid 1995; Rissolo 1995; Taube 1995; see also Rissolo and Heidelberg 1998), and examined the effect of archaeological work on the modern community of Naranjal (Goldsmith-Jilote 1995).

Our 1993 investigations produced the first evidence that the extensive freshwater wetlands of the Yalahau region may have been utilized by the ancient Maya, as suggested by clustering of settlements around wetland margins, and a single rock-alignment feature constructed within the margin of the wetland adjacent to the site of Tumben-Naranjal (Fedick 1998: 115; Fedick and Hovey 1995: 92). In the spring of 1994, botanist Arturo Gómez Pompa reported to Fedick that he had found a rock-alignment feature well within the wetland at the El Edén Ecological Reserve (FIG. 2). A brief visit by Fedick in 1994, followed in 1995 by a season of environmental reconnaissance, revealed an extensive system of rock-alignment features within the El Edén wetland.

\section{The El Edén Wetland and Ecological Reserve}

The El Edén wetland consists of a large, shallow depression measuring approximately $5.5 \mathrm{~km} \mathrm{~N}-\mathrm{s}$ by $0.8 \mathrm{~km}$ $\mathrm{E}-\mathrm{W}$. This wetland is included within the El Edén Ecological Reserve, established in 1990 on a privately owned tract of 1492 ha (Gómez Pompa and Dirzo 1995). The entire wetland is subject to inundation during the rainy season (approximately June through December), while only small areas contain standing water throughout the year. Flooding of the wetland is caused by a combination of local inflow from heavy rains and a regional rise of the water table during the rainy season. The terrain surrounding the wetland is of very low relief, rising only a few meters within several kilometers of the wetland margin. This low terrain surrounding the wetland is subject to occasional flooding during years of unusually high rainfall.

Water within the wetland is clear and fresh, and supports a variety of species of very small fish, as well as many species of gastropods including the edible apple snail (Pomacea flagellata). The wetland also supports extensive periphyton communities - thick mats of microbiota that are attached to vegetation or rock. The complex periphyton communities include algae, bacteria, fungi, and animals, along with organic and inorganic detritus (see Wetzel 1983). Periphyton represents a vital component of many freshwater wetland ecosystems, providing the main source of food for grazing herbivores, such as gastropods, and contributing significantly to the cycling of nutrients, particularly nitrogen and phosphorus (see Batzer and Resh 1991; Doyle and Fisher 1994; Grimshaw et al. 1993; Lamberti et al. 1989; Lane 1991; Marks and Lowe 1989; Mulholland et al. 1994; Vymazal and Richardson 1995).

Within the wetland, vegetation zones are structured by topographic relief and associated hydro period. The lower areas of the wetland contain standing water throughout the year, and are dominated by cattail (Typha dominguensis) and water lily (Nyphaea spp.). Slightly higher areas subject to flooding or saturation through most of the year are dominated by dense stands of sawgrass (Cladium jamaicensis). As elevation gently rises, the sawgrass becomes more scattered and includes increasing numbers of palmetto or tasiste palm (Paurotis wrightii) and calabash trees (Crescentia cujete). Continuing up the elevation gradient (and decreasing hydro period), the next vegetation community is a swamp forest that includes logwood or palo tinto (Haematoxylon campechianum), black chechem (Metopium brownei), ya'axnik (Vitex gaumeri), nance (Byrsonima bucidaeifolia), and a stunted variety of sapote (Manilkara $z a$ pote).

The margin of the wetland is marked by a band of exposed limestone bedrock that is virtually free of soil. Within the wetland, soil depth averages about $20 \mathrm{~cm}$ over bedrock, and consists of peaty deposits over silt and silty clay. In the lower areas of the wetland, dominated by sawgrass and cattail communities, soils reach a maximum depth of about $40-80 \mathrm{~cm}$.

\section{Wetland Survey Methods and Results}

A full-coverage survey of the El Edén wetland was conducted under the direction of Fedick by a team of four to six archaeologists walking transects spaced at intervals of 10-20 $\mathrm{m}$, depending on the density of vegetation cover. The limit of the survey extended beyond the exposed bedrock margin of the wetland, and approximately $25 \mathrm{~m}$ into the surrounding upland forest. Orientation within the wetland was facilitated by an enlarged aerial photograph with a superimposed one-kilometer grid aligned to the Universal Transverse Mercator system as derived from a l:50,000-scale topographic map. Using the geo-referenced aerial photograph, the survey crew would occasionally verify their location by use of a satellite-based Global Positioning System (GPS) receiver. Each identified feature was mapped with a Brunton pocket-transit and tape mea- 


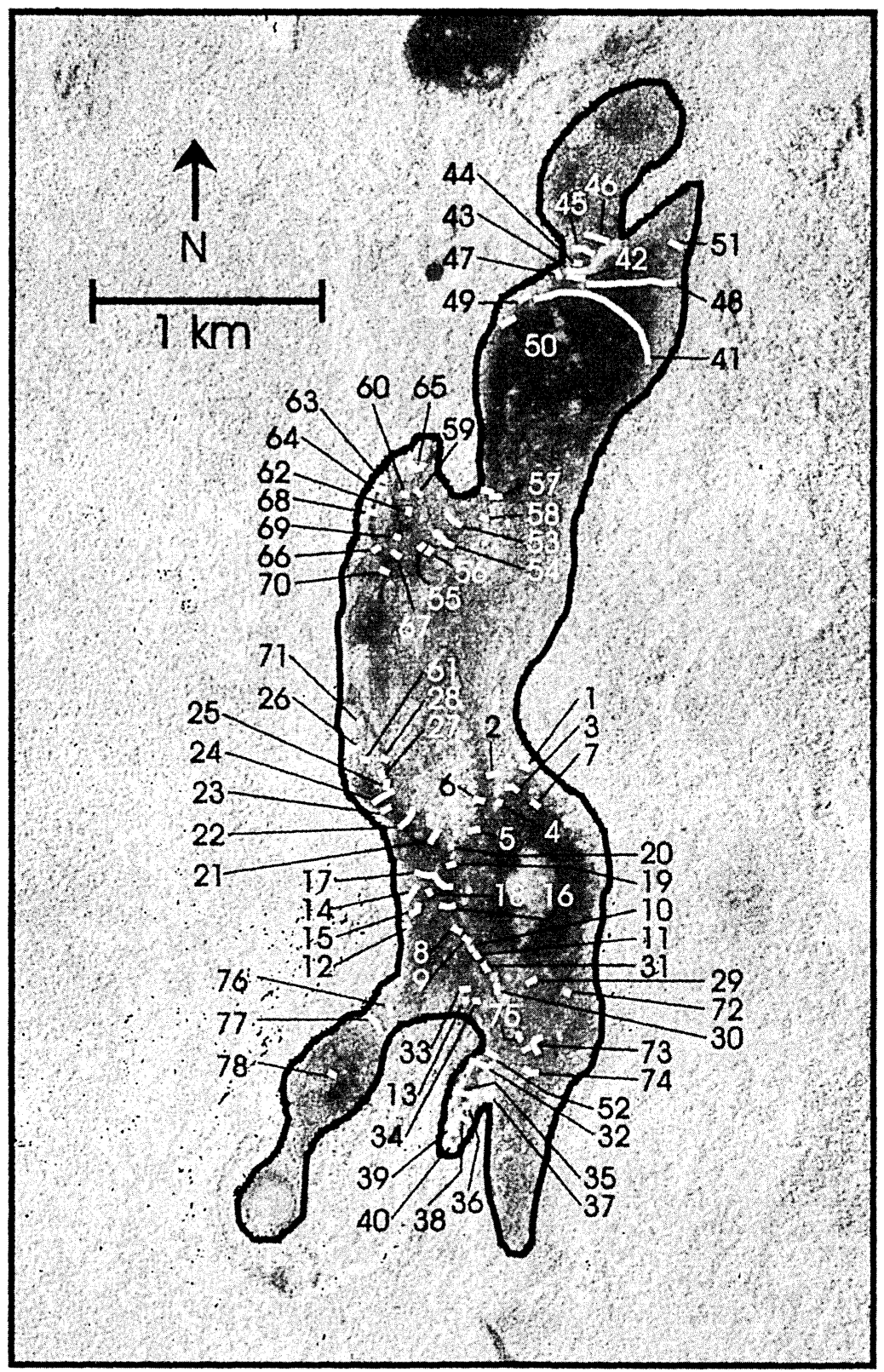

Figure 3. Aerial photograph of the El Edén wetland with numbered rock alignments superimposed. Black outline indicates the boundary of the survey.

sure, described by additional measurements, notes, and photographs, and labeled with a permanent aluminum tag. The location of each feature was determined with the use of the GPS receiver and marked on the aerial photograph.

A total of 78 features was recorded within the wetland (FIG. 3). These features consist of alignments of limestone boulders and slabs. The rock alignments range in length from a few meters to about $700 \mathrm{~m}$. Analysis of the distribution, length, and form of the alignments suggests that these features can be divided into five types that are associated with different physiographic settings within the wetland.

Type 1: long alignments that close off major sections of the wetland. The most prominent features recorded during the survey are two alignments of limestone slabs and boulders in the northern end of the wetland, stretching between the west and east margins (FIG. 3, Alignments $4 \mathrm{I}$ and 48).

Alignment 41 , the longest feature recorded, is about 


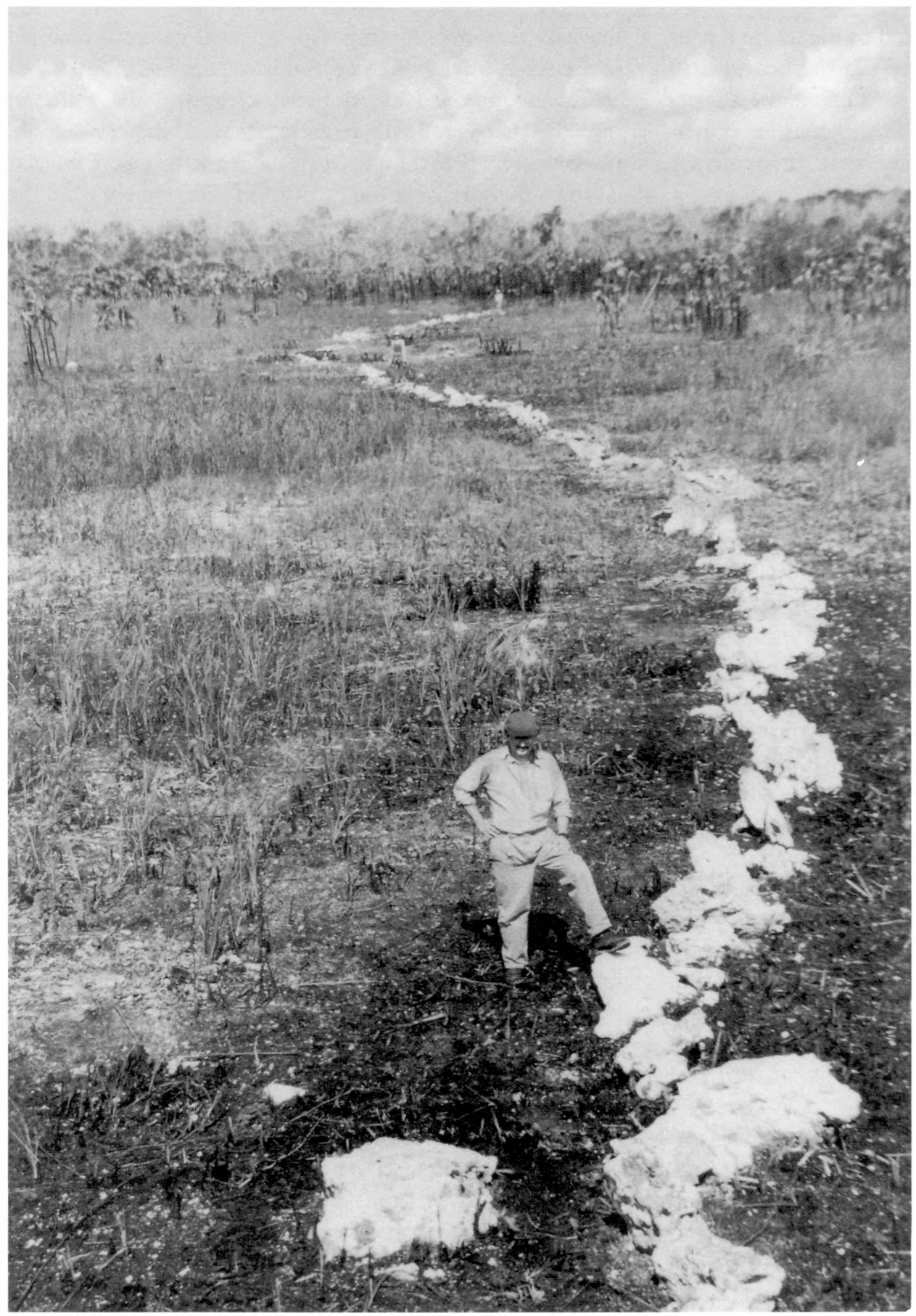

Figure 4. Western end of Alignment 41, facing west.

$700 \mathrm{~m}$ long and traverses seasonally inundated land dominated by sawgrass and tasiste palm, crossing some areas containing calabash trees (FIG. 4). The eastern and western ends of Alignment $4 \mathrm{l}$ terminate at the exposed bedrock margin of the wetland. Boulders range from approximately $40-70 \mathrm{~cm}$ in diameter, and slabs average about $15 \mathrm{~cm}$ in thickness with maximum diameters up to $115 \mathrm{~cm}$. The rocks are arranged in single to double rows, with several segments of slabs remaining in upright positions, supported on one or both sides by smaller boulders. It is estimated that Alignment 41 consists of over 2000 large boulders and slabs, representing a substantial investment of labor. 
Type 2: alignments that are situated to block the lowest margin of shallow natural depressions in the bedrock. In the northern and southern ends of the wetland are a series of smaller alignments associated with the margins of natural depressions (10-25 $\mathrm{m}$ in diameter) that are in turn situated within the courses of shallow channels (e.g., FIG. 3, Alignments 36, 38-40, 42-47, and 51). The alignments are situated so as to block the lowest terrain along the depression margin. These alignments are constructed of limestone boulders averaging about $30-40 \mathrm{~cm}$ in diameter, in single to double rows, occasionally reaching two or three courses in height.

Type 3: alignments that run perpendicular to slight slope gradients within higher areas of the wetland (e.g., FIG. 3, Alignments $35,53,54,57$, and 77 ), in fairly open transitional vegetation zones containing a scattering of swampforest species and sawgrass. Construction techniques and sizes of rocks are quite variable. Several of these alignments display a distinctive zigzag shape (Alignments 35,57 , and 77).

Type 4: alignments that run perpendicular to the slope leading into the larger depressions within the wetland, generally along the transition zone between lower areas with sawgrass and cattail, and higher areas with swamp forest (e.g., FIG. 3, Alignments 1-11). These alignments are generally constructed from single rows of boulders averaging about $60 \mathrm{~cm}$ in diameter.

Type 5: alignments that run perpendicular to and across narrow, relatively deep channels that are dominated by cattail (e.g., FIG. 3, Alignments 32, 52, and 63 through 68). These cross-channel alignments vary in length from $10 \mathrm{~m}$ to $66 \mathrm{~m}$, and are constructed of limestone boulders or slabs, ranging from about $40 \mathrm{~cm}$ to $70 \mathrm{~cm}$ in diameter.

\section{Test Excavations}

Test excavations at rock-alignment features were conducted under the direction of Andersen and Fedick. A representative feature was selected for test excavation from four of the five types of alignments defined above. Test excavation of a cross-channel alignment (Type 5) could not be conducted due to water levels within the channels. The features selected for excavation were: Alignments $4 \mathrm{I}$ (Type 1), 42 (Type 2), 57 (Type 3), and 11 (Type 4).

All excavation units measured $2 \times 2 \mathrm{~m}$ and were excavated as natural stratigraphic layers with further division into $10 \mathrm{~cm}$ levels as necessary. Two levels of recovery were used during the excavations. Intensive recovery methods were applied to the matrix from one excavation unit at each feature. The matrix from that unit was water screened using stacked $1 / 8$-inch and $1 / 4$-inch mesh screens. Water screening was facilitated in the field by the use of a portable gaso- line-powered water pump. Any cultural material retained in the screens was collected. A 4 liter sample of the materials retained in the 1/8-inch mesh screen was also collected in order that very small artifacts or faunal materials could be recovered. Soil samples for pollen analysis were collected from the surface of the excavation unit, from within the excavated matrix, and from the near-bottom of the unit. After completing the first excavation unit using the intensive methods described above, subsequent units were excavated using $1 / 4$-inch mesh screen and without collecting any additional soil samples.

\section{Alignment 41}

Alignment 41 (Type 1 ) was the longest rock-alignment feature recorded during the survey (FIG. 4). Four units were excavated at Alignment 41 , at approximately $260 \mathrm{~m}$ along the alignment from the eastern terminus (FIG. 5). The intensive recovery methods described above were used during the excavation of Unit A, while Units B, C, and D were excavated by the less intensive method.

Depth from surface to bedrock averaged about $20 \mathrm{~cm}$. The soil was silty clay loam and dark yellowish brown in color (Munsell color 10YR 4/4). The bedrock exposed at the bottom of each unit was consolidated, gently undulating, with a few small depressions and fissures.

By exposing the rocks that form the alignment, some details of construction technique could be discerned (FIG. 6). This segment of the alignment is constructed of limestone slabs that average about $60 \mathrm{~cm}$ across and $10 \mathrm{~cm}$ in thickness. The slabs were stood on edge and retained in an upright position by wedging them between limestone boulders that range in diameter from approximately 10-30 $\mathrm{cm}$.

Quantification of gravel retained after $1 / 4$-inch screening revealed that substantially more water-worn limestone gravel was present in the excavation unit centered over the alignment than was recovered from the adjacent excavation units located away from, and on either side of, the alignment. This water-worn gravel does not seem to have originated from the bedrock, which forms a relatively hard and smooth cap, and is unlikely to be fully explained by deterioration of the slabs and boulders that make up the alignment. It is possible that the concentration of water-worn gravel along the length of the alignment represents inclusions that have eroded out of an earthen berm that may have originally been constructed over the rock alignment. The slabs and boulders that make up Alignment 41 may be the remnants of a structural foundation for a much more substantial earthen construction that has eroded away.

Recovery of artifacts in association with the feature proved to be problematic. Ten small; highly eroded frag- 


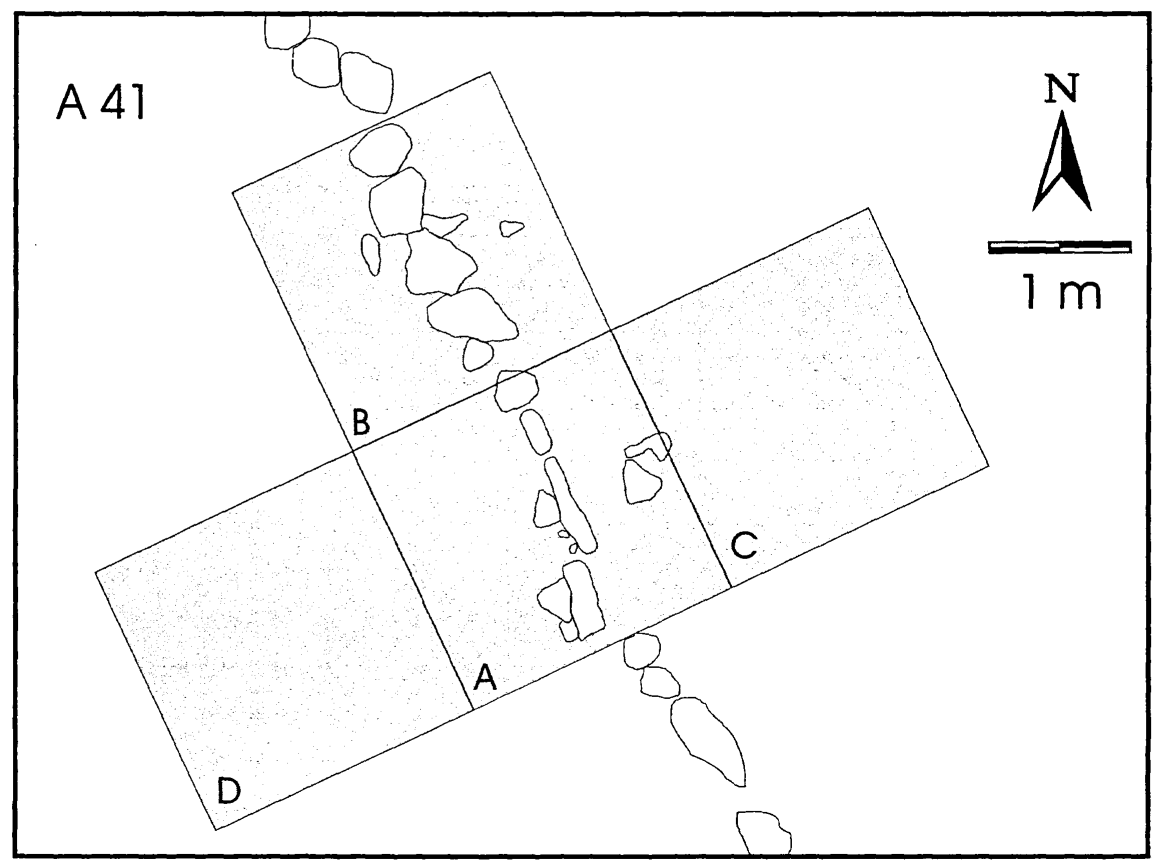

Figure 5. Plan view of Alignment 41 after excavation.

ments of what appear to be coarse redware ceramics were recovered from excavation Units A and B, but cannot be identified as to form or type.

\section{Alignment 42}

Alignment 42 (Type 2) was constructed along the southern margin of a natural depression in the limestone bedrock that measures about $30 \mathrm{~m}$ in diameter (FIG. 7). The depression is dominated by sawgrass and contains standing water during most of the year. The terrain surrounding the depression is primarily exposed bedrock with patches and pockets of thin soil that support a sparse swamp forest association. The lowest edge of the depression is the southern margin which faces the main body of the wetland to the south. A series of similar depressions are scattered along a low corridor that runs north from the northern end of the wetland. Three units were excavated at Alignment 42 (FIG. 8). The intensive recovery methods described above were used during the excavation of Unit A, while Units B and C were excavated by the less intensive method.

Depth from surface to bedrock averaged about $7 \mathrm{~cm}$ with a silty clay loam soil, that was dark reddish brown in color (Munsell color 5YR 3/4). The bedrock exposed at the bottom of each unit was broken and uneven. Excavations revealed that Alignment 42 was constructed of limestone boulders and slabs that ranged between $20 \mathrm{~cm}$ and $40 \mathrm{~cm}$ in diameter. The arrangement suggests that many of the slabs were originally placed in an upright position and supported by surrounding boulders, similar to the construction of Alignment 41 . The broken character of the bedrock at Alignment 42 prohibited distinguishing whether there was a concentration of gravel along the alignment as was noted at Alignment 41. No artifacts were recovered in association with Alignment 42.

\section{Alignment 57}

Alignment 57 (Type 3) is the northernmost of a series of three alignments $(53,54$, and 57$)$ that appear to run perpendicular to a slight slope gradient that runs downward to the ssw. Alignment 57 has a distinctive zigzag shape to it. This portion of the wetland appears to flood only during the height of the rainy season, and is dominated by tasiste palm and nance trees. Soils in this zone are relatively deep in comparison with most of the wetland as well as the surrounding uplands. Two units were excavated at Alignment 57 (FIG. 9). The intensive recovery methods described above were used during the excavation of Unit A, while Unit B was excavated by the less intensive method.

Depth from surface to bedrock averaged about $20 \mathrm{~cm}$. The soil was silty clay loam and dark reddish brown in color (Munsell color 5YR 3/4). Bedrock exposed at the bottom of the excavation units was very uneven and broken. Excavation revealed that Alignment 57 consists of many more rocks than are visible at the ground surface. It ap- 


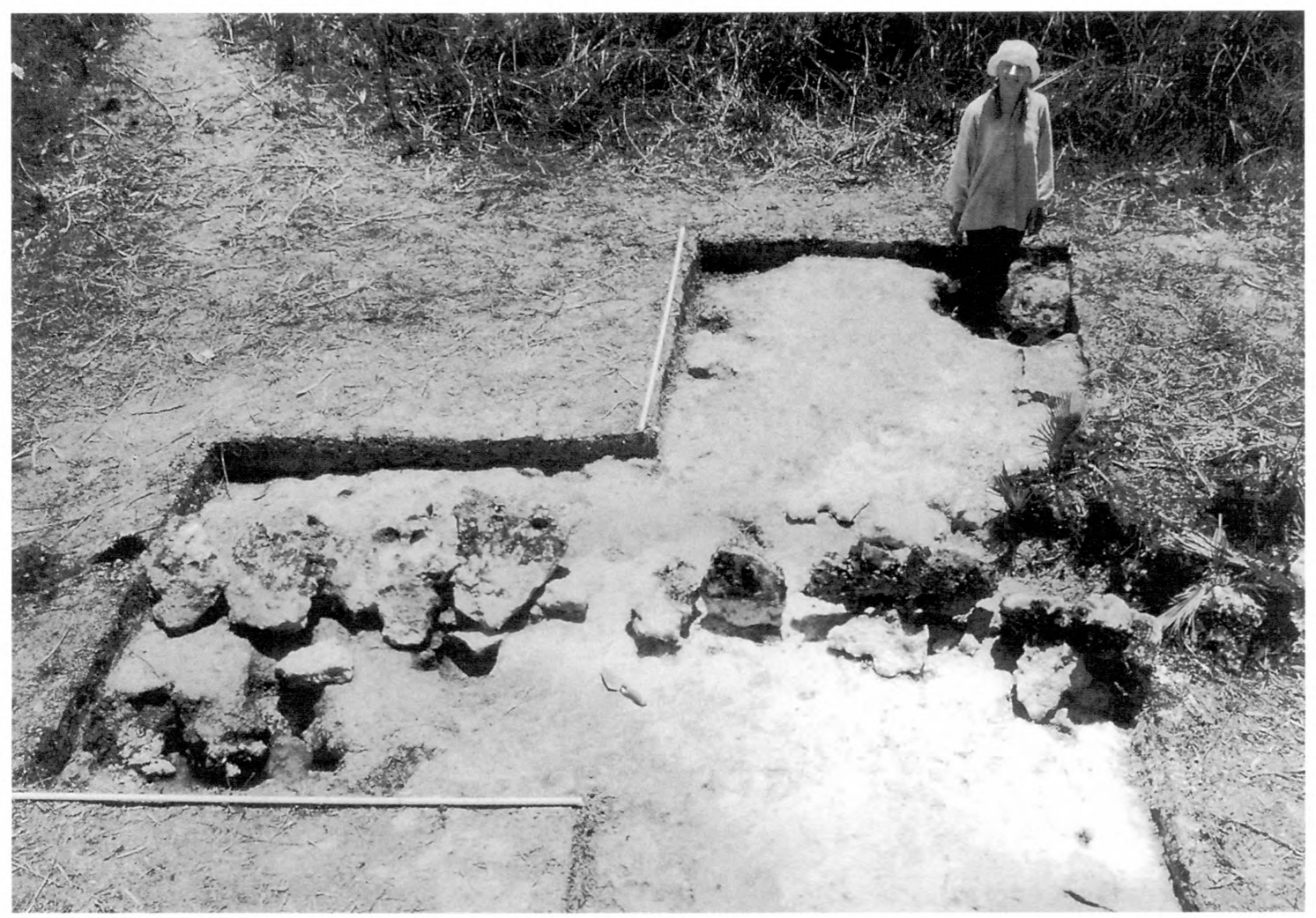

Figure 6. Alignment 41 after excavation to bedrock. Note boulders bracing slabs at the right end of the excavation. View facing NE.

pears that rocks were piled up to form an alignment with a fairly consistent top elevation, while compensating for low areas in the bedrock. A small amount of friable red mineral material was collected from Unit A during excavation and may represent degraded ceramics. No other artifacts were recovered in association with Alignment 57.

\section{Alignment 11}

Alignment 11 (Type 4) is one of a series of alignments ( 8 through 11 and 30 through 31 ) that run parallel to the longer margins of a wide linear depression within the southern part of the wetland. Within the linear depression, vegetation is dominated by sawgrass and cattail, while the alignment is situated on slightly higher ground to the east, where sawgrass and calabash trees predominate.

One unit was excavated at Alignment 11 (FIG. IO). Owing to difficulties with the water pump, the matrix excavated at Alignment 11 was dry-screened with $1 / 4$-inch mesh. Samples were collected according to the intensive recovery methods described above.

Depth from surface to bedrock averaged about $20 \mathrm{~cm}$. The soil was a silty clay, dark yellowish brown in color (Munsell color 5Y 4/1). The bedrock exposed at the bot- tom of the excavation units was undulating with some fragmentation. The excavated part of Alignment 11 was constructed of limestone boulders and cobbles that ranged from $20-50 \mathrm{~cm}$ in diameter. Only a few small limestone slabs were present, and the alignment is best characterized as a line of boulders with cobbles piled along the sides. No artifacts were recovered in association with Alignment 11.

\section{Discussion and Interpretation}

\section{Human versus Natural Origin of Rock Alignments}

One of the central debates over evidence for ancient Maya wetland management is the ability of researchers to distinguish features that are the result of human construction rather than products of natural formation processes (e.g., Dunning 1996: 57; Harrison 1996: 188-190; Pope, Pohl, and Jacob 1996). The rock alignments recorded as features within the El Edén wetland are of definite human construction, and can not be explained by natural processes. Excavation of Alignment 41 in particular demonstrates a consistent pattern in which limestone slabs were placed in an upright position and braced on one or both sides with boulders to hold them in place. At Alignment 41, ex- 


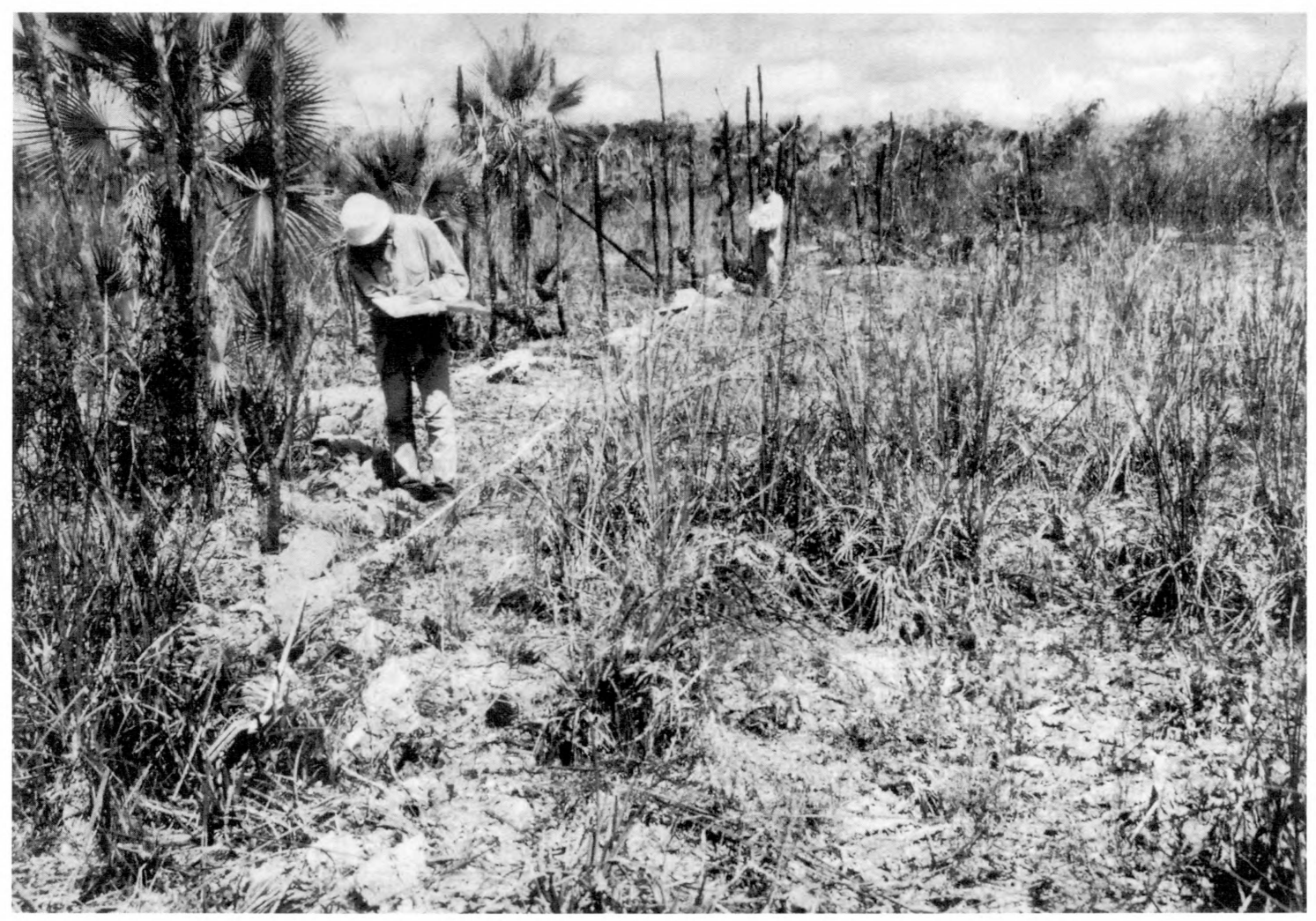

Figure 7 . Alignment 42 facing west. The alignment follows the southern margin of a small natural depression shown on the right side of the photograph.

cavations revealed that the rocks forming the alignment rested on a smooth, hard cap of bedrock, with no evidence of natural bedrock breakage or exfoliation.

The limestone slabs that were often used in the construction of the alignments can be found exfoliating around the margins of the wetland and along the margins of smaller depressions within the wetland. In a few locations, these exfoliating slabs separated from the stratified bedrock at natural "steps" in the terrain and sometimes produced an "alignment" of several flat-lying slabs. This natural formation process was easily recognizable, and could not explain the origin of any alignments recorded as features.

During survey we noted a few cases in which fallen trees had pulled several boulders and slabs into upright positions that could possibly remain erect after the tree would have rotted away. This circumstance, however, could only produce an alignment of a couple of meters at most, and we were careful not to record alignments of only a few slabs or boulders as archaeological features.

\section{Chronology of Wetland Use}

The test excavations at rock alignment features did not recover artifacts that could have been useful for assigning dates to the construction or use of the features. Only a small amount of fragmentary, red, and sometimes friable material that may represent degraded ceramic sherds was recovered. Chronological assessment of wetland use must therefore depend on dating of other nearby sites and activities associated with the wetland.

The only known human activity in the vicinity of El Edén that dates to the Historical period is associated with the chicle (a tree sap used for chewing gum production) and logging industry during the late 1800s and early 1900s (Andrews 1985). Rail lines were constructed in the region to transport chicle and wood for export, and one of these rail lines, known to have crossed the El Edén wetland (Fedick, Reid, and Mathews 1995), is still visible. The tracks ran along the top of a raised bed constructed of limestone boulders and gravel; still present are many wooden ties and in some places remnants of metal rails. The raised bed of the rail line is distinctly different from the rock alignments, and there is no evidence that the alignments have any association with the chicle and logging industries. An abundance of historical artifacts is associated with the rail line, and no historical artifacts were recovered in asso- 


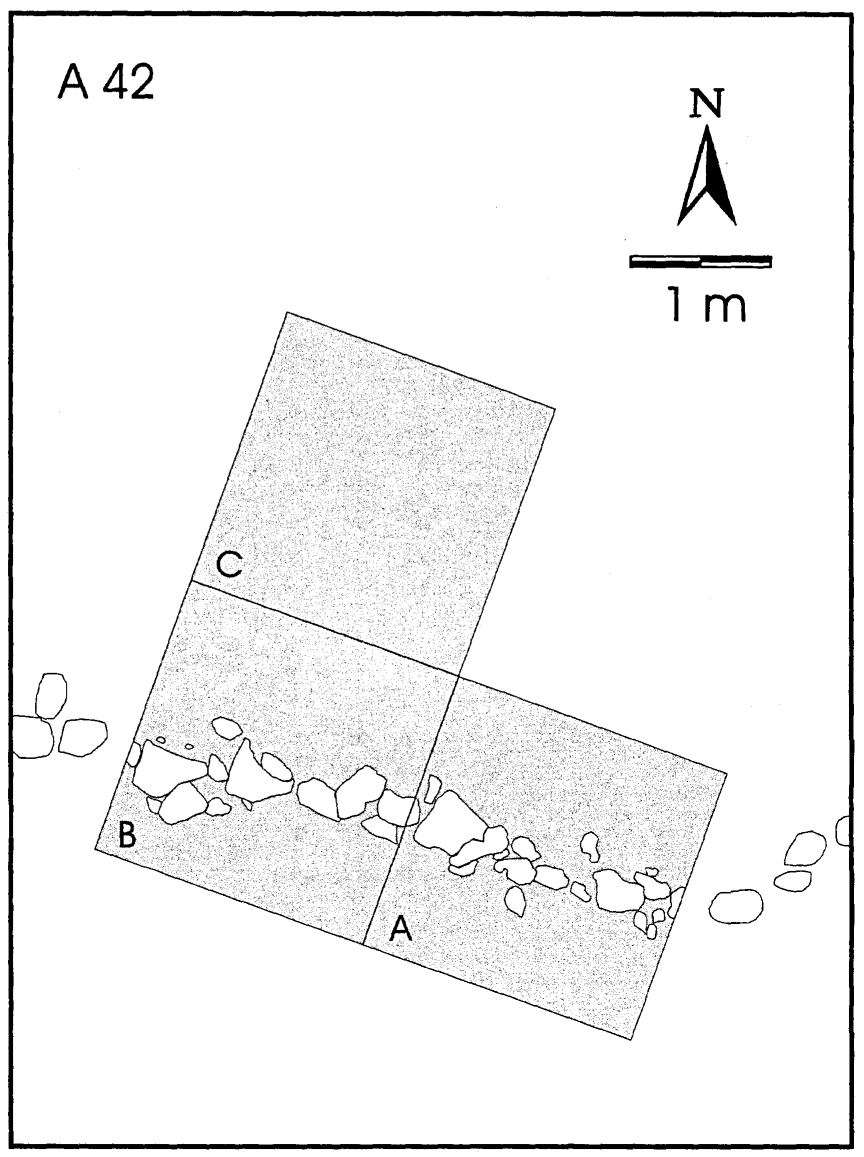

Figure 8. Plan view of Alignment 42 after excavation.

ciation with the rock alignments. Additionally, no histori$\mathrm{cal}$ artifacts were noted during survey anywhere in the wetland except with the rail line.

The closest investigated prehistoric site to the El Edén wetland is the small ancient community of Makabil, mapped and excavated by Morrison as part of a settlement study in the El Edén area (Morrison 2000). For the settlement study, a total of 64 ha was surveyed along a transect that stretches between the eastern margin of the El Edén wetland and the small center of Cenote Azul, situated 4.1 $\mathrm{km}$ east of the wetland (FIG. 2). Investigations focused on Makabil, a community of 60 structures with an associated cenote, located $2.7 \mathrm{~km}$ from the wetland margin. The site lies just east of a ridge that defines the apparent extreme high-flood zone of the wetland. A total of 17 test units was excavated off the edges of 15 structures at Makabil. A total volume of about 20 liters of ceramics was recovered during excavations, and chronologically diagnostic sherds were identified from excavation units associated with 14 of the 15 tested structures (TABLE I). Preliminary type-variety analyses of the ceramics by Sylviane Boucher and Kevin
Hovey identified the assemblage as corresponding to the Añejo complex as described by Robles Castellanos (1990) at Cobá. This complex, developing out of Preclassic complexes, but containing bichromes and showing an absence of polychromes, has been referred to as both Late Preclassic and as Protoclassic, with approximate dates of 100 B.C. to A.C. 350 (Andrews et al. 1988; Robles Castellanos 1990). Following the range of dates that is most often given for this chronological transition in northern Quintana Roo, we use A.C. 350 as the approximate termination for the Late Preclassic in the Yalahau region, while recognizing that refinement of the ceramic chronology for the northern lowlands is an ongoing process (Bey et al. 1998; Brady et al. 1998; Canché Manzanero 1992; Hernández Hernández and Chung 1995; Kepecs 1998; Peraza Lope 1999; Suhler, Ardren, and Johnstone 1998).

The ancient community of T'isil is situated about $10 \mathrm{~km}$ south of Makabil, and $3 \mathrm{~km}$ east of a large wetland that is very similar to El Edén (FIG. 2). Reconnaissance of the wetland next to T'isil has revealed a system of rock-alignment features similar to that of the El Edén wetland. Extensive surface collections made at T'isil during 1999 and 2000 provide an expanded chronology when compared to Makabil, while maintaining evidence for a mainly Late Preclassic occupation. At Tisil, surface collections from a stratified random sample of 62 structures produced a total of 2519 sherds that have been identified through type-variety analysis by Ceja Acosta (TABLE I). Approximately $95 \%$ of the ceramics, representing all 62 collected structures, are diagnostic of the Late Preclassic period. Evidence for occupation after the Late Preclassic is sparse. Only about 1\% of the ceramics, scattered among 7 structures, are diagnostic of the Early Classic period (ca. A.C. 350-600). The Terminal Classic/Early Postclassic (ca. A.c. 1000-1200) is represented at three structures by less than $1 \%$ of the total ceramics. The Late Postclassic (ca. A.c. 1200-1550) is represented at three structures, by approximately $4 \%$ of the total ceramics.

The chronology developed for the sites of Makabil and T'isil indicates that the strongest evidence for settlement in the vicinity of the El Edén wetland is during the Late Preclassic period between approximately 100 B.C. and A.C. 350 . We tentatively assign these dates to the construction and use of features in the El Edén wetland, recognizing the need for further testing of this hypothesis in the future. The little evidence for Early Classic occupation at T'isil may represent a minor presence that extended into that period. It is interesting to note that $98 \%$ of the total ceramics that are diagnostic of the Terminal Classic/Early Postclassic and Late Postclassic periods were recovered from two structures that are next to each other, suggesting that 
Table 1. Ceramic types identified at the sites of Makabil and T'isil.

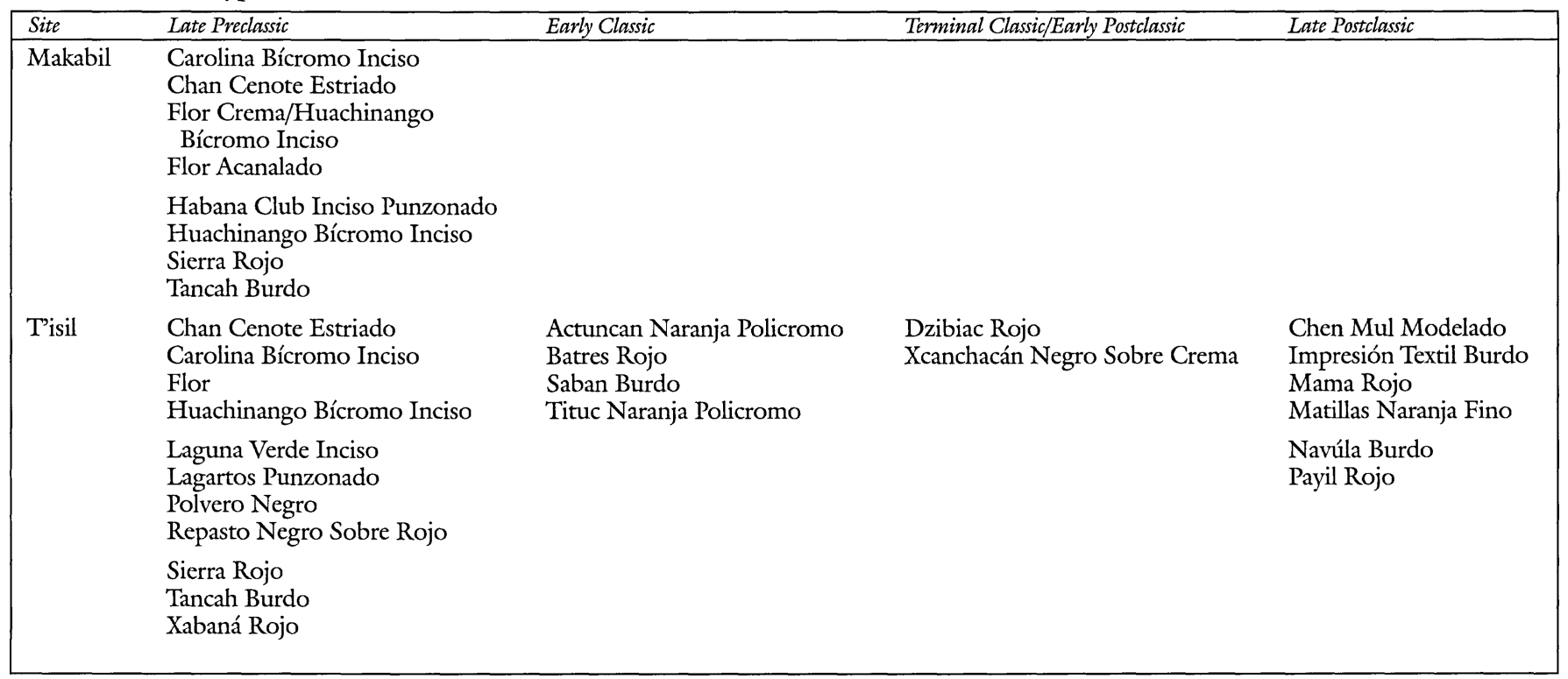

they might represent a small group of people that reoccupied the site after a long abandonment (see Lorenzen 1999 for a discussion of Late Postclassic presence in the Yalahau region). Known activities of the Historical period in the vicinity of El Edén are restricted to chicle and logging operations that would not have involved wetland management.

\section{Environmental Change}

The interpretation of ancient use of the El Edén wetland must take into account evidence that the climate and hydrology of the region has probably not remained constant over time. Recent studies suggest that climate (and by extension, seasonal variability in the water table) in the northern Maya Lowlands has fluctuated through the last 3000 years (Curtis, Hodell, and Brenner 1996; Hodell, Curtis, and Brenner 1995; Leyden et al. 1994; see also Gill 2000). Analysis and interpretation of a lake sediment core from Punta Laguna, just south of the Yalahau region, indicate a rather dramatic shift to drier conditions beginning about A.C. 280, and continuing until about A.c. 1080 (Curtis, Hodell, and Brenner 1996: fig. 6). The onset of the dry period at about A.C. 280 coincides quite closely with the apparent abandonment (or near abandonment) by about A.C. 350 of the two settlements (Makabil and T'isil) most closely associated with the El Edén wetland.

Other studies have identified a trend in sea-level rise that continued at a gradual rate after the Pleistocene, in turn raising the water table of the karstic Yucatán Peninsula (Alcala Herrera et al. 1994; Coke, Perry, and Long 1991;
Dunn and Mazzullo 1993; Fairbanks 1989; Folan, Kintz, and Fletcher 1983: 43-48; McKillop 1995). Current evidence suggests that the water table of the Yalahau region may have been lower than today, possibly by as much as a meter, when nearby settlements were occupied during the Late Preclassic/Early Classic periods. If this were the case, the El Edén wetland would still have been a wetland, but with lower flood levels and shorter hydro periods.

\section{Construction Technique and Function}

Ancient rock-alignment features in non-wetland settings are widespread in the northern lowlands, but the context, form, and apparent function differ significantly from the features recorded in the El Edén wetland. Elsewhere in the northern lowlands, rock alignments have been recorded in well-drained upland settings as albaradas (stone walls), and are interpreted as ancient boundary markers, most often enclosing household compounds, and sometimes delineating nearby plots apparently used for intensive cultivation or for protection and cultivation of useful trees (e.g., Andrews and Andrews 1975; Bullard 1952, 1954; Fletcher 1983; Fletcher and Kintz 1983; Freidel and Sabloff 1984; Gómez Pompa, Flores, and Sosa 1987; Goñi Motilla 1993; Kepecs and Boucher 1996; Morrison 2000; Sierra Sosa 1994; Silva Rhodes and María del Carmen Hernández 1991; Vlcek, Garza de González, and Kurjack 1978). In Maya villages today, enclosed household compounds are known as solares, and contain the various domestic structures used by a family, as well as open activity space, a variety of useful trees, enclosures for domestic animals, and 


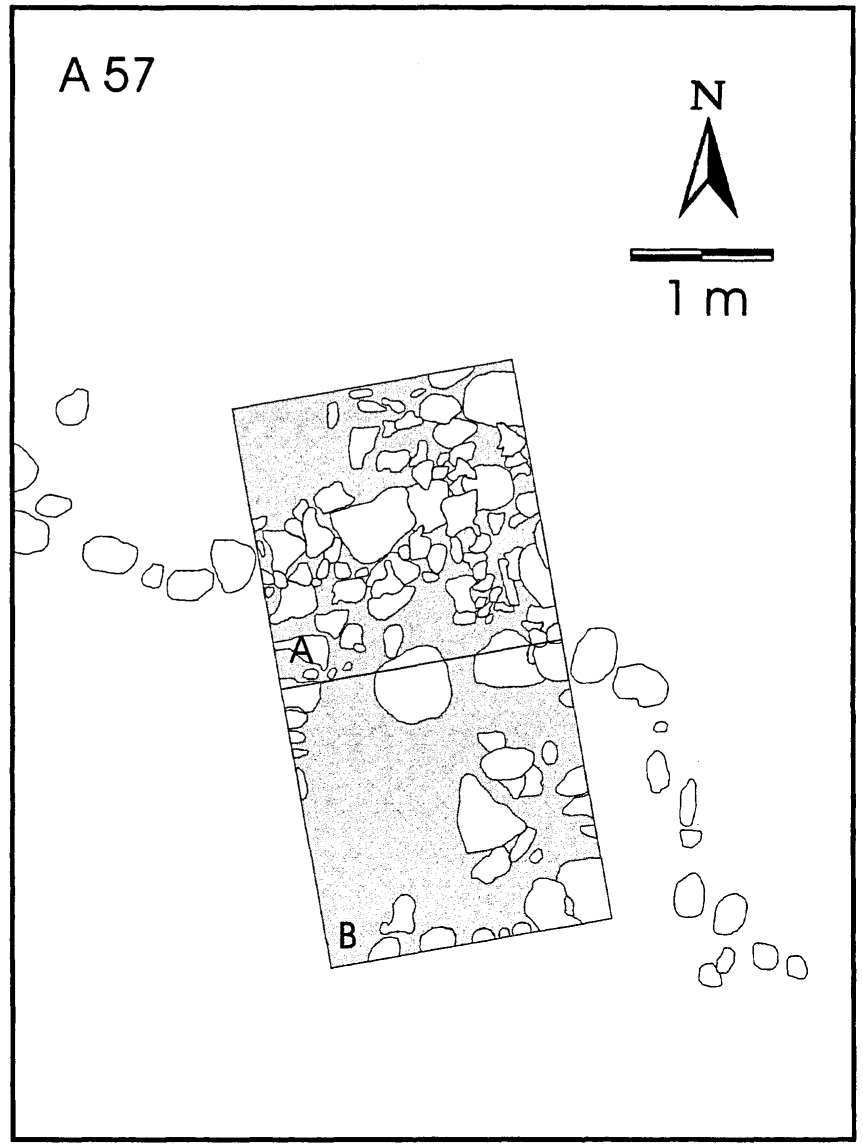

Figure 9. Plan view of Alignment 57 after excavation.

home gardens (Acosta Bustillos, Flores, and Gómez Pompa 1998; Anderson 1993, 1995; de Jong 1999; Fletcher and Kintz 1983; Herrera Castro 1994; Herrera Castro et al. 1993; Ortega et al. 1993). Wall systems such as these have been recorded within the Yalahau region at the ancient communities of Makabil and T'isil, and we interpret those features as boundary markers that define ancient solares (Morrison 2000). In contrast, the rock-alignment features within the El Edén wetland are in a very different physical context (a wetland), do not enclose spaces, and are not in direct association with any domestic architecture or other features.

The El Edén wetland features are not reminiscent of the salt pans described by Anthony Andrews (1983) for the coastal marshes, where earthen berms are constructed, sometimes over or around logs, wooden stakes, and rock alignments, to form rectilinear evaporation enclosures (see also Sierra Sosa 1999: 43). The El Edén wetland is far enough from the coast to exclude brackish water intrusion. It is highly unlikely that salt production could ever have been a function of the El Edén wetland features, as sea lev- el in the past was lower than today, limiting brackish water intrusion in the past to areas farther north than we see currently in the Yalahau wetlands.

The features most similar to anything in the El Edén wetland are the features interpreted as dikes within the shallow margins of Lakes Cobá and Macanxoc, located within the site of Cobá, about $50 \mathrm{~km}$ south of the Yalahau region at the terminus of the Holbox fracture zone (Folan 1983: 43-44, figs. 3.14, 3.15). The Cobá dikes appear superficially similar to El Edén Alignment 41 , the $700 \mathrm{~m}$ alignment that closes off the northern end of the wetland. The Cobá dikes seem to be more substantial features, and are associated with a body of water that is significantly deeper than the Yalahau wetlands. There is no evidence that the Cobá lakes were ever modified for agricultural purposes, and sediment studies at Lake Cobá suggest to investigators that the dikes were constructed at about A.C. 380 in order to form a reservoir (Leyden, Brenner, and Dahlin 1998).

Further studies will be necessary in order to determine the exact function of the rock-alignment features and the nature of wetland management at El Edén. Some preliminary hypotheses, however, have been developed and are currently being investigated. Based primarily on the results of excavations at Alignment 4l, it is suggested that at least some of the rock alignments represent the foundations, or internal support structures, for earthen berms that were constructed to control the flow of water in the wetland during rains.

Most of the rock alignments identified so far are situated around the sloping margins of two large depressions in the northern and southern ends of the wetland (FIG. 3) that represent the most extensive tracts of relatively deep soil, now dominated by sawgrass and cattail. If the water table was significantly lower during the time when the wetland was under management, then a major portion of the wetland would have been spared from flooding, except perhaps during the height of the rainy season. The long alignments closing off the north end of the wetland may have served as breakwaters or dikes to protect cultivated areas from runoff being channeled by natural relief into the wetland from the north. Within the main body of the wetland and between the two largest depressions, alignments that run perpendicular to gentle slopes may have functioned to slow runoff and encourage sediment deposition. Where natural channels occur within the wetland, the cross-channel alignments would have functioned as check dams to slow the rush of rainwater into the large, lower depressions. The check dams would also facilitate the buildup of sediments behind their walls and within associated depressions, which could also have been used for cultivation. 


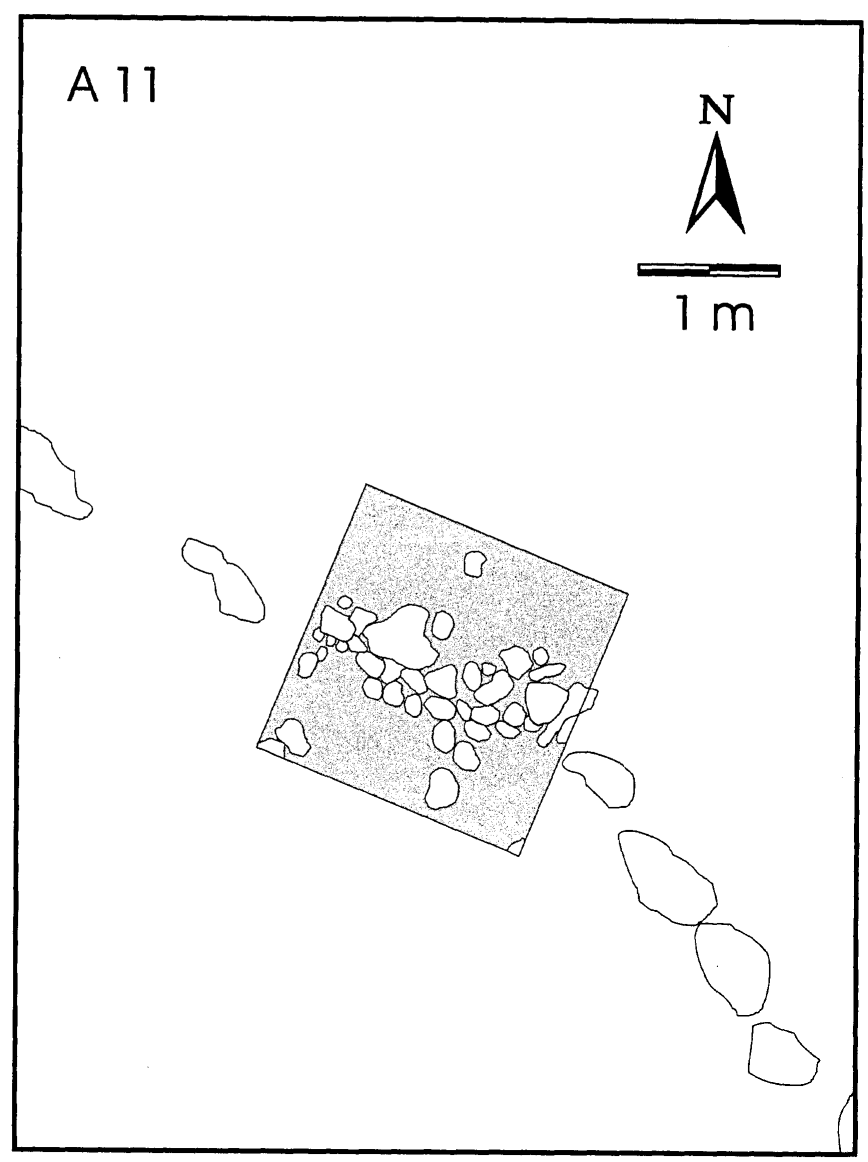

Figure 10. Plan view of Alignment 11 after excavation.

The seasonality of cultivation would have been dependent on the hydrological regime active at the time of use, but it is likely that planting would have been scheduled either as a flood-recessional system at the close of the rainy season, or as a late dry-season crop, referred to today as a marceño (March), that involves the planting of maize varieties (or other crops such as cotton) that are tolerant of flooding (see Carter 1969; Culbert, Magers, and Spencer 1978; Gliessman 1991; Wilk 1985; Wilken 1987: 149-151). Unfortunately, pollen preservation in samples from the excavations at the rock alignments was very poor and provided no evidence of domestic crops.

We are also exploring the possibility that ancient management of the wetlands may have functioned to increase the productivity of wetland resources as an alternative or supplement to cultivation of domestic crops such as maize or cotton. The abundance of edible wetland resources such as cattail, tasiste palm, and apple snails is determined in large part by hydrological conditions that could have been manipulated by the ancient Maya to increase productivity of these resources. Another intriguing possibility is that the abundant periphyton that grow within the El Edén wetland may have had a significant role in the agricultural ecology of the region. Preliminary analysis of periphyton samples from El Edén by Ana Luisa Anaya, a chemical ecologist with the National Autonomous University of Mexico, indicates very high levels of phosphorus, nitrogen, and organic matter, and a very high cation exchange capacity-all indicators of high fertility for plant growth (Vymazal and Richardson 1995). Moreover, phosphorus is the primary limiting nutrient for agriculture in the northern Maya Lowlands. We are exploring the possibility, along with our colleagues, that periphyton could have functioned as a natural, renewable, and manageable source of agricultural fertilizer. Dried periphyton could have easily been transported and applied as fertilizer in home gardens or upland agricultural fields.

\section{Extent and Intensity of Wetland Manipulation and Comparison with Other Areas}

Based upon the evidence collected from the El Edén wetland, it is anticipated that other wetlands of the Yalahau region were also managed, with techniques varying to suit the specific physical settings of the individual wetlands. Reconnaissance has already identified a system of rock-alignment features within the wetland located just south of El Edén, on the lands of Rancho Santa Maria and in association with the ancient community of T'isil.

The extent of wetlands within the Yalahau region is comparable to that of the wetland zone associated with the New River and Río Hondo of northern Belize, currently the most studied area of ancient wetland management in the southern Maya Lowlands (e.g., Berry and McAnany 1998; Harrison 1996; Pohl 1990; Pohl and Bloom 1996; Pohl et al. 1996; Pope, Pohl, and Jacob 1996; Turner and Harrison 1983). Although comparable in geographic scale, the wetland management systems of northern Belize and the Yalahau region are very dissimilar. The wetlands of northern Belize, as is the case with other reported sites of ancient Maya wetland management in the southern lowlands (e.g., Culbert, Levi, and Cruz 1990; Culbert et al. 1997; Gliessman et al. 1983), were manipulated either by digging canals through the deep soils of the wetland margins, or by constructing raised planting platforms within the main body of the wetland. Neither of these management techniques is evident in the El Edén wetland, where control of water and retention of sediments was facilitated by check dams, dikes, and various other features represented today by rock alignments.

How intensively the Yalahau wetlands were managed is not yet known. Although the features recorded at El Edén do represent a substantial investment of labor, the features 
would certainly represent a lower labor investment than the construction of raised-bed wetland cultivation systems, and may be comparable with lower-intensity systems of channelized fields.

\section{Conclusions}

Investigations within the El Edén wetland and at sites in the immediate vicinity provide evidence for a previously unreported form of wetland management in the Maya Lowlands, most likely to have been in use during the Late Preclassic period, between approximately 100 B.C. and A.C. 350 . The numerous rock alignments recorded in the wetland apparently represent features that functioned to control the movement of water and soil within the natural depression, allowing either the cultivation of domestic crops or the encouragement of edible or economically useful wetland resources. Features similar to those in the El Edén wetland are known to exist in at least one adjacent wetland, and if common throughout the wetlands of the Yalahau region, would represent a major region of wetland management.

The cause of the apparent abandonment of settlements associated with the El Edén wetland by about A.C. 350 is not known, although a strong possibility exists that the hydrology of the wetlands may have been altered by the onset of an extended dry period at about that time, in combination with a gradually rising water table. Changes in hydrology may have rendered the El Edén wetland unsuitable for management, as has been suggested for wetland systems in northern Belize (Pohl, Bloom, and Pope 1990; Pohl et al. 1996; Pope, Pohl, and Jacob 1996). Rather than focusing on the abandonment of the El Edén wetland management system, it may be more useful to view use of the wetlands during the Late Preclassic as taking advantage of natural conditions when they were at an optimum for economic production. The management of wetlands in the Yalahau region represents another innovative form of landscape manipulation and resource use within the complex mosaic of ecosystems that constitute the Maya Lowlands.

It is increasingly apparent that ancient Maya agriculture was not based on any single cultivation system or even on a fixed set of techniques. Rather, it was an innovative and flexible system that took advantage of local resource endowments and was able to adjust and adapt to changing conditions in a manner that sustained large regional populations over many centuries within a landscape best considered a managed mosaic (Fedick, ed. 1996).

\section{Acknowledgments}

Research of the Yalahau Regional Human Ecology Project was conducted under permit of the Instituto Nacional de Antropología e Historia (INAH). We are grateful for the assistance of Juaquín García-Bárcena, current President of the Consejo de Arqueologia, and Noberto González Crespo, past President of the Consejo, for their assistance in the permit process, and to INAH archaeologists Maria José Con Uribe, Luis Leira, Sara Novela, Fernando Robles Castellanos, Enrique Terrones, and Adriana Velázquez Morlet for their assistance and interest in our project. We appreciate the invitation by Arturo Gómez Pompa to conduct an archaeological investigation of the El Edén wetland. Our work at the El Edén Ecological Reserve was greatly facilitated by Marco Lazcano, Arturo Gómez Pom$\mathrm{pa}$, and the staff of the reserve. Sylviane Boucher's analysis of ceramics from the 1996 excavations was conducted with the assistance of Sara Dzul G. of the Escuela de Antropología, Universidad Autónoma de Yucatán. Ceramics from the 1997 excavations at Makabil were identified by Kevin Hovey of the Department of Anthropology, University of California, Riverside. Pollen samples from excavations at El Edén were analyzed by Dawn Digrius and John Jones.

The 1996-1997 field work at El Edén was provided by crew members Daniel Baum, Julie Bell, Dawn Digrius, Aaron Gardner, Kurt Heidelberg, Natasha Johnson, Carrie Lambert, Aline Mangoni, Rani McLean, Ivan Miranda, Shanti Morell-Hart, Matthew Moriarty, and Darcy Wiewall, and by numerous enthusiastic volunteers of the University Research Expeditions Program. Field work at the site of T'isil during 1998-1999 was conducted with the assistance of Fabio Estaban Amador B., Xiomara Carpeño, Dawn Digrius, Felix Fenenoz, Jeff Glover, Shawna Gunnarson, Kurt Heidelberg, Anna Hoover, Kevin Hovey, Edyn Jessup, Helen Neylan, Dominique Rissolo, Alan Robinson, Melisa Roldan, Karlos Santos-Coy, Kathy Sorensen, and Dennis Taylor.

The 1996-1997 research of the Yalahau project was supported by grants from the UC MEXUS program of the University of California, the Foundation for the Advancement of Mesoamerican Studies, the University Research Expeditions Program of the University of California, and the National Science Foundation (Award No. SBR9600956). Financial support for the final analysis and write-up of the 1996-1997 project, and funding for 1998-2000 research at T'isil, was generously provided by Michael Baker, owner of Rancho Santa Maria. This paper was revised by Scott Fedick while on a resident fellowship with the University of California Humanities Research Institute.

Scott L. Fedick (Ph.D. Arizona State University, 1988) is an 
Associate Professor of Anthropology at the University of California, Riverside, and has been Director of the Yalahau Regional Human Ecology Project since it was initiated in 1993. He has conducted field research in California, Washington state, and Arizona, as well as in Guatemala, Belize, and Mexico. His research interests include ancient Maya agriculture, settlement patterns, and community organization. Mailing address: Department of Anthropology, University of California, Riverside, CA 92521-0418.

Bethany Morrison (Ph.D. University of California, Riverside, 2000) is a specialist in Maya archaeology and bas conducted field research in Belize and Mexico. Her research interests include settlement patterns, buman ecology, community structure, ancient agriculture, the use of scientific method in archaeology, and the development of innovative teaching methods. Mailing address: 6 Hillview Drive East, New Fairfield, CT 06812.

Bente Jubl Andersen (B.A. University of Copenhagen, 1993) is currently enrolled in the graduate program at the Department of Prehistoric Archaeology, University of Copenbagen, Denmark. She has participated in field research in the Yalabau region since 1996 and her focus so far has been on resource management and agriculture. Mailing address: Department of American Indian Languages and Cultures, University of Copenhagen, Artillerivej 86, DK-2300, Copenbagen, Denmark.

Sylviane Boucher (M.A. Universidad de las Américas, Puebla, México, 1979) bas, since 1980, been a Research Professor with the National Institute of Anthropology and History (INAH) of Mexico. She has worked in the Department of Prehispanic Monuments and in the INAH Yucatan Regional Center since 1982, and is curently in charge of the Ceramoteca (ceramic laboratory) of the Centro INAH Yucatán. Mailing address: CRY-INAH Apartado Postal No. 79, Cordemex, Mérida, Yucatán 97110, México.

Jorge Ceja Acosta, a student at Universidad Veracruzana, is currently collaborating with the Yalahau project as a ceramicist and field associate. He is particularly interested in ceramic exchanges across different cultural horizons in the NE corner of the Yucatán Peninsula. Mailing address: Facultad de Antropologia, Universidad Veracruzana, Francisco Morono equ. Ezequiel Alatriste, Col. Ferrer Guardia, Xalapa, Veracruz 912020, México.

Jennifer Mathews (Ph.D. University of California, Riverside, 1998) has been an Associate Professor of Archaeology at Trinity University since 1999, and is currently Co-Director of the Yalahan Regional Human Ecology Project. She has conducted archaeological fieldwork in Mexico since 1993. Her research interests include ancient site layout, road systems and architecture. Mailing address: Department of Sociology and Anthropology, 715 Stadium Drive, Trinity University, San Antonio, TX 78212-7200.
Acosta Bustillos, Luz Elena, José Salvador Flores, and Arturo Gómez Pompa

1998 Uso y Manejo de Plantas Forrajeras para Cría de Animales del Solar en una Comunidad Maya en Yucatán. Etnoflora Yucatanense 14. Mérida: Universidad Autónoma de Yucatán.

Adams, Richard E. W., W. E. Brown, Jr., and T. Patrick Culbert

1981 "Radar Mapping, Archaeology, and Ancient Maya Land Use," Science 213: 1457-1463.

Alcala Herrera, J. A., J. S. Jacob, M. L. Machain Costillo, and R. W. Neck

1994 "Holocene Paleosalinity in a Maya Wetland, Belize, Inferred from the Microfaunal Assemblage," Quaternary Research 41: 121-130.

Anderson, Eugene N.

1993 "Gardens in Tropical America and Tropical Asia," Biotica, nueva época 1: 81-102.

1995 "Natural Resource Use in a Maya Village", in Scott L. Fedick and Karl A. Taube, eds., The View From Yalabau: 1993 Archaeological Investigations in Northern Quintana Roo, Mexico. Latin American Studies Program, Field Report Series 2. Riverside: University of California, 139-148.

Andrews, Anthony P.

1983 Maya Salt Production and Trade. Tucson: University of Arizona Press.

1985 "The Archaeology and History of Northern Quintana Roo," in W. C. Ward, A. E. Weidie, and W. Back, eds., Geology and Hydrogeology of the Yucatan and Quaternary Geology of the Northern Yucatan Peninsula. New Orleans: New Orleans Geological Society, 127-143.

Andrews, Anthony P., Tomás Gallareta Negrón, Fernando Robles Castellanos, Rafael Cobos Palms, and Pura Cervera Rivero

1988 "Isla Cerritos: an Itzá Trading Port on the North Coast of Yucatán, Mexico," National Geographic Research 4 (2): 196-207.

Andrews, E. Wyllys, IV, and Anthony P. Andrews

1975 A Preliminary Study of the Ruins of Xcaret, Quintana Roo, Mexico, with Notes on Other Archaeological Remains on the Central Coast of the Yucatán Peninsula. Middle American Research Institute Publication 40. New Orleans: Tulane University.

Andrews, E. Wyllys, IV, and George E. Stuart

1975 "The Ruins of Ikil, Yucatan, Mexico," in Margaret Harrison and Robert Wauchope, eds., Archaeological Investigations on the Yucatan Peninsula. Middle American Research Institute, Publication. New Orleans: Tulane University, 69-80.

Back, William, and Bruce B. Hanshaw

1970 "Comparison of Chemical Hydrogeology of the Carbonate Peninsulas of Florida and Yucatan," Journal of Hydrology 10 : 330-368.

Batzer, D. P., and V. H. Resh

1991 "Trophic Interactions among a Beetle Predator, a Chironomid Grazer, and Periphyton," Oikos 60: 251-257.

Berry, Kimberly, and Patricia A. McAnany

1998 "Bogged Down in Wetland Controversy: Current Investigations at K'axob, Belize," Context $13(3-4)$ : 1-4.

Bey, George J., III, Tara M. Bond, William M. Ringle, Craig A. Hanson, Charles W. Houch, and Carlos Peraza Lope

1998 "The Ceramic Chronology of Ek Balam, Yucatan, Mexico," Ancient Mesoamerica 9: 101-121. 
Brady, James E., Joseph W. Ball, Ronald L. Bishop, Duncan C. Pring, Norman Hammond, and Rupert A. Housley

1998 'The Lowland Maya 'Protoclassic': A Reconsideration of its Nature and Significance," Ancient Mesoamerica 9: 17-38.

Bullard, William R., Jr.

1952 Residential Property Walls at Mayapan. Carnegie Institution of Washington, Department of Archaeology, Current Report 3. Washington, D.C.: Carnegie Institution of Washington.

1954 Boundary Walls and House Lots at Mayapan. Carnegie Institution of Washington, Department of Archaeology, Current Report 13. Washington, D.C.: Carnegie Institution of Washington.

Canché Manzanero, Elena de la Cruz

1992 La Secuencia Cerámica de Xelhá, Quintana Roo. Tesis de Licenciatura, Facultad de Ciencias Antropológicas de la Universidad Autónoma de Yucatán, Mérida.

Carter, William E.

1969 New Lands and Old Traditions: Kekchi Cultivators in the Guatemalan Highlands. Gainesville: University of Florida Press.

Coke, James, E. C. Perry, and Austin Long

1991 "Sea-Level Curve," Nature 353: 25.

Culbert, T. Patrick., Laura J. Levi, and Luís Cruz

1990 "Lowland Maya Wetland Agriculture: The Rio Azul Agronomy Program," in Flora S. Clancy and Peter D. Harrison, eds., Vision and Revision in Maya Studies. Albuquerque: University of New Mexico Press, 115-124.

Culbert, T. Patrick, Pamela C. Magers, and Mara L. Spencer

1978 "Regional Variability in Maya Lowland Agriculture," in Peter D. Harrison and B. L. Turner II, eds., Pre-Hispanic Maya Agriculture. Albuquerque: University of New Mexico Press, 157-161.

Culbert, T. Patrick, Vilma Fialko, Brian McKee, Liwy Grazioso, Julie

Kunen, and Leonel Paez

1997 "Investigaciones Arqueológicas en el Bajo la Justa, Peten," in Juan Pedro Laporte and Héctor L. Escobedo, eds., $X$ Simposio de Investigaciones Arqueológicas en Guatemala. Guatemala City: IDAEH, 367-371.

Curtis, Jason H., David A. Hodell, and Mark Brenner

1996 "Climate Variability on the Yucatan Peninsula (Mexico) during the Past 3500 Years, and the Implications for Maya Cultural Evolution," Quaternary Research 46: 37-47.

de Jong, Harriet J.

1999 "The Land of Corn and Honey. The Keeping of Stingless Bees (Meliponiculture) in the Ethno-Ecological Environment of Yucatan (Mexico) and El Salvador," unpublished $\mathrm{Ph} . \mathrm{D}$. dissertation, Utrecht University, the Netherlands.

Doyle, R. D., and T. R. Fisher

1994 "Nitrogen Fixation by Periphyton and Plankton on the Amazon Floodplain at Lake Calado," Biogeochemistry 26: 41-66.

Duller, Charles E.

1990 A Case for Archaeological Reconnaissance of the Cabo CatochePorvenir Region of the Northeastern Yucatan Peninsula. NASA Technical Memorandum 102248. Moffett Field, CA: Ames Research Center.

Dunn, Richard K., and S. J. Mazzullo

1993 "Holocene Paleocoastal Reconstruction and its Relationship to Marco Gonzalez, Ambergris Caye, Belize," Journal of Field Archaeology 20: 121-131.
Dunning, Nicholas P.

1996 "A Reexamination of Regional Variability in the Prehistoric Agricultural Landscape," in Scott L. Fedick, ed., The Managed Mosaic: Ancient Maya Agriculture and Resource Use. Salt Lake City: University of Utah Press, 53-68.

Dunning, Nicholas, Timothy Beach, Pat Farrell, and Sheryl Luzzadder-Beach

1998 "Prehispanic Agrosystems and Adaptive Regions in the Maya Lowlands," Culture and Agriculture 20: 87-101.

Escalona Ramos, Alberto

1946 "Algunas Ruinas Prehispanicas en Quintana Roo," Boletin de la Sociedad Mexicana de Geografia y Estadistica 61: 513-628.

Fairbanks, Richard G.

1989 "A 17,000-year Glacio-Eustatic Sea Level Record: Influence of Glacial Melting Rates in the Younger Dryas Event and Deep-Ocean Circulation," Nature 342: 637-642.

Fedick, Scott L.

1996 "Introduction: New Perspectives on Ancient Maya Agriculture and Resource Use," in Scott L. Fedick, ed., The Managed Mosaic: Ancient Maya Agriculture and Resource Use. Salt Lake City: University of Utah Press, 1-14.

1998 "Ancient Maya Use of Wetlands in Northern Quintana Roo, Mexico," in Kathryn Bernick, ed., Hidden Dimensions: The Cultural Significance of Wetland Archaeology. Vancouver: University of British Columbia Press, 107-129.

Fedick, Scott L., editor

1996 The Managed Mosaic: Ancient Maya Agriculture and Resource Use. Salt Lake City: University of Utah Press.

Fedick, Scott L., and Kevin Hovey

1995 "Ancient Maya Settlement and Use of Wetlands at Naranjal and the Surrounding Yalahau Region,” in Scott L. Fedick and Karl A. Taube, eds., The View From Yalabau: 1993 Archaeological Investigations in Northern Quintana Roo, Mexico. Latin American Studies Program, Field Report Series 2. Riverside: University of California, 89-100.

Fedick, Scott L., and Karl A. Taube

1995 "The Yalahau Regional Human Ecology Project: Research Orientation and Overview of 1993 Investigations," in Scott L. Fedick and Karl A. Taube, eds., The View From Yalahau: 1993 Archaeological Investigations in Northern Quintana Roo, Mexico. Latin American Studies Program, Field Report Series 2. Riverside: University of California, 1-21.

Fedick, Scott L., and Karl A. Taube, editors

1995 The View From Yalabau: 1993 Archaeological Investigations in Northern Quintana Roo, Mexico. Latin American Studies Program, Field Report Series 2. Riverside: University of California.

Fedick, Scott L., Dawn Reid, and Jennifer P. Mathews

1995 "Preliminary Evidence for the Existence of a Regional Sacbe Across the Northern Maya Lowlands," in Scott L. Fedick and Karl A. Taube, eds., The View From Yalahau: 1993 Archaeological Investigations in Northern Quintana Roo, Mexico. Latin American Studies Program, Field Report Series 2. Riverside: University of California, 129-137.

Fletcher, Laraine A.

1983 "Linear Features in Zone I: Description and Classification" in William J. Folan, Ellen R. Kintz, and Laraine A. Fletcher, Cobá: A Classic Maya Metropolis. New York: Academic Press, 89-102. 
Fletcher, Laraine, and Kintz, Ellen R.

1983 "Solares, Kitchen Gardens, and Social Status at Cobá," in William J. Folan, Ellen R. Kintz, and Laraine A. Fletcher, Cobá: A Classic Maya Metropolis. New York: Academic Press, 103-119.

Folan, William J.

1983 "Physical Geography of the Yucatan Peninsula," in William J. Folan, Ellen R. Kintz, and Laraine A. Fletcher, Cobá: $A$ Classic Maya Metropolis. New York: Academic Press, 21-48.

Folan, William J., Ellen R. Kintz, and Laraine A. Fletcher

1983 Cobá: A Classic Maya Metropolis. New York: Academic Press.

Freidel, David A., and Jeremy A. Sabloff

1984 Cozumel: Late Maya Settlement Patterns. New York: Academic Press.

Gill, Richardson Benedict

2000 The Great Maya Droughts: Water, Life, and Death. Albuquerque: University of New Mexico Press.

Gliessman, Stephen R.

1991 "Ecological Basis of Traditional Management of Wetlands in Tropical Mexico: Learning from Agroecosystems," in Margery L. Oldfield and Janis B. Alcorn, eds., Biodiversity: Culture, Conservatism, and Ecodevelopment. Boulder, CO: Westview Press, 211-229.

Gliessman, Stephen R., B. L. Turner, II, Francisco J. Rosado May, and M. F. Amador

1983 "Ancient Raised Field Agriculture in the Maya Lowlands of Southeastern Mexico," in Janice P. Darch, ed., Drained Field Agriculture in Central and South America. BAR International Series 189. Oxford: B.A.R., 91-110.

Goldsmith-Jilote, Kim

1995 "The Development for Tourism of the Archaeological Site of Naranjal: A People's Perspective," in Scott L. Fedick and Karl A. Taube, eds., The View From Yalahau: 1993 Archaeological Investigations in Northern Quintana Roo, Mexico. Latin American Studies Program, Field Report Series 2. Riverside: University of California, 149-151.

Gómez Pompa, Arturo, and Rodolpho Dirzo

1995 Reservas de la Biosfera y Otras Areas Naturales Protegidas de México. México, D.F.: Instituto Nacional de Ecología.

Gómez Pompa, Arturo, Jose Salvador Flores, and Victoria Sosa

1987 "The 'Pet Kot': A Man-Made Tropical Forest of the Maya," Interciencia 12 (1): 10-15.

Goñi Motilla, Guillermo Antonio

1993 "Solares Prehispanicos en la Peninsula de Yucatan," unpublished thesis at the Escuela Nacional de Antropologia e Historia, Mexico City.

Grimshaw, H. J., M. Rosen, D. R. Swift, K. Rodberg, and J. M. Noel

1993 "Marsh Phosphorous Concentrations, Phosphorus Content and Species Composition of Everglades Periphyton Communities," Archiv fir Hydrobiologie 128: 257-276.

Harrison, Peter D.

1993 "Aspects of Water Management in the Southern Maya Lowlands," in Vernon Scarborough and Barry L. Isaac, eds., Economic Aspects of Water Management in the Prehispanic World. Research in Economic Anthropology, Supplement 7. Greenwich, CT: JAI Press, 71-119.

1996 "Settlement and Land Use in the Pulltrouser Swamp Archaeological Zone," in Scott L. Fedick, ed., The Managed
Mosaic: Ancient Maya Agriculture and Resource Use. Salt Lake City: University of Utah Press, 177-190.

Hernández Hernández, Concepción, and Heajoo Chung

1995 "Secuencia cerámica preliminar del Sitio Arqueológico de Playa del Carmen, Quintana Roo," in Memorias del Segundo Congreso Internacional de Mayistas. México, D.F.: Universidad Nacional Autónoma de México, 389-406.

Herrera Castro, Natividad Delfina

1994 Los Huertos Familiares Mayas en el Oriente de Yucatán. Etnoflora Yucatanense 9. Mérida: Universidad Autónoma de Yucatán.

Herrera Castro, Natividad, Arturo Gómez Pompa, Luis Cruz Kuri, and José Salvador Flores

1993 "Los Huertos Familiares Mayas en X-uilub, Yucatán, México. Aspectos Generales y Estudios Comparative entre la Flora de los Huertos Familiares y la Selva," Biotica, nueva época 1: 19-36.

Hodell, David A., Jason H. Curtis, and Mark Brenner

1995 "Possible Role of Climate in the Collapse of Maya Civilization," Nature 375: 391-394.

Isphording, W. C.

1975 "The Physical Geology of the Yucatan," Transactions, Gulf Coast Association of Geological Societies 25: 231-262.

Kepecs, Susan

1998 "Diachronic Evidence and its Social Implications in the Chikinchel Region, Northeastern Yucatan, Mexico," $A n$ cient Mesoamerica 9: 121-135.

Kepecs, Susan, and Sylviane Boucher

1996 "The Pre-Hispanic Cultivation of Rejolladas and StoneLands: New Evidence from Northeast Yucatán," in Scott L. Fedick, ed., The Managed Mosaic: Ancient Maya Agriculture and Resource Use. Salt Lake City: University of Utah Press, 69-91.

Konrad, Herman

1985 "Fallout of the Wars of the Chacs: The Impact of Hurricanes and Implications for Prehispanic Quintana Roo Maya Processes," in M. Thompson, M. T. Garcia, and F. J. Kense, eds., Status, Structure and Stratification: Current Archaeological Reconstructions. Calgary: Archaeological Association, University of Calgary, 321-330.

Lamberti, G. A., S. V. Gregory, L. R. Ashkenas, A. D. Steinman, and C. D. McIntire

1989 "Productive Capacity of Periphyton as a Determinant of Plant Herbivore Interactions in Streams," Ecology 70: 1840-1856.

Lane, J. M.

1991 "The Effect of Variation in Quality and Quantity of Periphyton on Feeding Rate and Absorption Efficiencies of the Snail Neritina reclivata (Say)," Journal of Experimental Marine Biology and Ecology 150: 117-129.

Leyden, Barbara W., Mark Brenner, and Bruce H. Dahlin

1998 "Cultural and Climatic History of Cobá, a Lowland Maya City in Quintana Roo, Mexico," Quaternary Research 48: 111-122.

Leyden, Barbara W., Mark Brenner, David A. Hodell, and Jason H. Curtis

1994 "Orbital and Internal Forcing of Climate on the Yucatan Peninsula for the Past ca. 36 ka," Palaeogeography, Palaeoclimatology, Palaeoecology 109: 193-210. 
López Ornat, Arturo

1983 "Nota que Reporta la Existencia de un Canal Artificial en la Provincia Prehispánica de Uaimil, Bahía de la Ascensión, Quintana Roo," Boletin de la Escuela de Ciencias Antropologicas de la Universidad de Yucatán 10 (80): 39-43.

Lorenzen, Karl James

1995 "Late Postclassic Reuse of Early Classic Monumental Architecture at Naranjal," in Scott L. Fedick and Karl A. Taube, eds., The View From Yalabau: 1993 Archaeological Investigations in Northern Quintana Roo, Mexico. Latin American Studies Program, Field Report Series 2. Riverside: University of California, 59-77.

1999 "New Discoveries at Tumben-Naranjál: Late Postclassic Reuse and the Ritual Recycling of Cultural Geography," Mexicon 21: 98-107.

McKillop, Heather

1995 "Underwater Archaeology, Salt Production, and Coastal Maya Trade at Stingray Lagoon, Belize," Latin American Antiquity 6: 214-228.

Marks, J. C., and R. L. Lowe

1989 "The Independent and Interactive Effects of Snail Grazing and Nutrient Enrichment on Structuring Periphyton Communities," Hydrobiologia 185: 9-17.

Matheny, Ray

1976 "Maya Lowland Hydraulic Systems," Science 193: 639-646.

1978 "Northern Maya Lowland Water-Control Systems," in Peter D. Harrison and B. L. Turner II, eds., Pre-Hispanic Maya Agriculture. Albuquerque: University of New Mexico Press, 185-210.

Mathews, Jennifer P.

1995 "The Box Ni Group of Naranjal, and Early Architecture of the Central Maya Lowlands," in Scott L. Fedick and Karl A. Taube, eds., The View From Yalahaw: 1993 Archaeological Investigations in Northern Quintana Roo, Mexico. Latin American Studies Program, Field Report Series 2. Riverside: University of California, 79-88.

1998 The Ties That Bind: The Ancient Maya Interaction Spheres of the Late Preclassic and Early Classic Periods in the Northern Yucatan Peninsula. Ph.D. dissertation, University of California, Riverside. Ann Arbor: University Microfilms.

Millet Cámara, Luis

1984 "Logwood and Archaeology in Campeche," Journal of Anthropological Research 40: 324-328.

Morrison, Bethany

2000 "Ancient Maya Settlement of the Yalahau Region: An Example from the El Edén Wetland," unpublished Ph.D. dissertation, University of California, Riverside.

Mulholland, P. J., A. D. Steinman, E. R. Marzolf, D. R. Hart, and D.

L. Deangelis

1994 "Effect of Periphyton Biomass on Hydraulic Characteristics and Nutrient Cycling in Streams," Oecologia 98: 40-47.

Ortega, Luz María, Sergio Avendaño, Arturo Gómez Pompa, and Edilberto Ucán Ek

1993 “Los Solares de Chunchucmil, Yucatán, México," Biotica, nueva época 1: 37-51.

Peraza Lope, Carlos A.

1999 Estudio y Secuencia del Material Cerámico de San Gervasio, Cozumel. Tesis de Licenciatura, Facultad de Ciencias
Antropológicas de la Universidad Autónoma de Yucatán, Mérida.

Pohl, Mary D., editor

1990 Ancient Maya Wetland Agriculture: Excavations on Albion Island, Northern Belize. Boulder, CO: Westview Press.

Pohl, Mary D., and Paul Bloom

1996 "Prehistoric Maya Farming in the Wetlands of Northern Belize: More Data from Albion Island and Beyond," in Scott L. Fedick, ed., The Managed Mosaic: Ancient Maya Agriculture and Resource Use. Salt Lake City: University of Utah Press, 145-164.

Pohl, Mary D., Paul R. Bloom, and Kevin O. Pope

1990 "Interpretation of Wetland Farming in Northern Belize: Excavations at San Antonio, Río Hondo," in Mary D. Pohl, ed., Ancient Maya Wetland Agriculture: Excavations on Albion Island, Northern Belize. Boulder, CO: Westview Press, 187-237.

Pohl, M. D., K. O. Pope, J. G. Jones, J. S. Jacob, D. R. Piperno, S. D. de France, D. L. Lentz, J. A. Gifford, M. E. Danforth, and J. K. Josserand

1996 "Early Agriculture in the Maya Lowlands," Latin American Antiquity 7: 355-372.

Pope, Kevin O., and Bruce H. Dahlin

1989 "Ancient Maya Wetland Agriculture: New Insights from Ecological and Remote Sensing Research," Journal of Field Archaeology 16: 87-106.

1993 "Radar Detection and Ecology of Ancient Maya Canal Systems-Reply to Adams et al.", Joumal of Field Archaeology 20: 379-383.

Pope, Kevin O., Mary D. Pohl, and John S. Jacob

1996 "Formation of Ancient Maya Wetland Fields: Natural and Anthropogenic Processes," in Scott L. Fedick, ed., The Managed Mosaic: Ancient Maya Agriculture and Resource Use. Salt Lake City: University of Utah Press, 165-176.

Reid, Dawn M.

1995 "Inter- and Intra-Site Sacbeob of the Naranjal Area," in Scott L. Fedick and Karl A. Taube, eds., The View From Yalahau: 1993 Archaeological Investigations in Northern Quintana Roo, Mexico. Latin American Studies Program, Field Report Series 2. Riverside: University of California, 121-128.

Rissolo, Dominique

1995 "An Archaeological Investigation of Tacbi Ha Cave, Naranjal," in Scott L. Fedick and Karl A. Taube, eds., The View From Yalahau: 1993 Archaeological Investigations in Northern Quintana Roo, Mexico. Latin American Studies Program, Field Report Series 2. Riverside: University of California, 115-120.

Rissolo, Dominique, and Kurt Heidelberg

1998 "The Yalahau Archaeological Cave Survey," NSS News, June. National Speleological Society.

Robles Castellanos, Fernando

1990 La Sequencia Cerámica de la Region de Cobá, Quintana Roo. Mexico City: Instituto Nacional de Antropología e Historia.

Roys, Ralph L., and Edwin M. Shook

1966 Preliminary Report on the Ruins of Ake, Yucatan. Society for American Archaeology Memoirs 20, Vol. 31 (3): 1-54. 
Sanders, William

1955 "An Archaeological Reconnaissance of Northern Quintana Roo," Carnegie Institution of Washington Department of Archaeology Current Reports 2 (24): 179-219.

1960 Prehistoric Ceramics and Settlement Patterns in Quintana Roo, Mexico. Contributions to American Anthropology and History 12 (60). Carnegie Institution of Washington Publication 606. Washington, D.C.: Carnegie Institution of Washington.

Scarborough, Vernon

1993 "Water Management in the Southern Maya Lowlands: An Accretive Model for the Engineered Landscape," in Vernon Scarborough and Barry L. Isaac, eds., Economic Aspects of Water Management in the Prehispanic New World. Research in Economic Anthropology, Supplement 7. Greenwich, CT: JAI Press, 17-69.

1994 "Maya Water Management" National Geographic Research and Exploration 10: 184-199.

Sidrys, Raymond

1978 "Megalithic Architecture and Sculpture of the Maya Area," in Raymond Sidrys, ed., Papers on the Economy and Architecture of the Ancient Maya. Institute of Archaeology, Monograph 7. Los Angeles: University of California, 155-183.

Siemens, Alfred H., and Dennis E. Puleston

1972 "Ridged Fields and Associated Features in Southern Campeche: New Perspectives on the Lowland Maya," American Antiquity 37: 228-239.

Sierra Sosa, Thelma Noemí

1994 Contribución al Estudio de los Asentamientos de San Gervasio, Isla de Cozumel. Serie Arqueología, Colección Cientifica 279. México, D.F.: Instituto Nacional de Antropología e Historia.

1999 "Xcambó: Codiciadao Enclave Económico del Clásico Maya," Arqueología Mexicana 7 (37): 40-47.

Silva Rhodes, Carlos, and Concepción María del Carmen Hernández

1991 Estudios de Patrón de Asentamiento en Playa del Carmen, Quintana Roo. Serie Arqueologia, Colección Cientifica 231. México, D.F.: Instituto Nacional de Antropología e Historia.

Southworth, C. Scott

1985 "Applications of Remote-Sensing Data, Eastern Yucatan," in W. C. Ward, A. E. Weidie, and W. Back, eds., Geology and Hydrogeology of the Tucatan and Quaternary Geology of Northeastern Yucatan Peninsula. New Orleans: New Orleans Geological Society, 12-19.

Suhler, Charles T., Traci Ardren, and David Johnstone

1998 "The Chronology of Yaxuna: Evidence from Excavation and Ceramics," Ancient Mesoamerica 9: 167-182.

Taube, Karl A.

1995 "The Monumental Architecture of the Yalahau Region and the Megalithic Style of the Northern Maya Lowlands," in Scott L. Fedick and Karl A. Taube, eds., The View From Yalabau: 1993 Archaeological Investigations in Northern Quintana Roo, Mexico. Latin American Studies Program, Field Report Series 2. Riverside: University of California, 23-58.

Tulaczyk, Slawomir M.

1993 "Karst Geomorphology and Hydrogeology of the Northeastern Yucatan Peninsula, Mexico," unpublished Master's thesis, Northern Illinois University, DeKalb.
Tulaczyk, Slawomir M., Eugene C. Perry, Charles E. Duller, and Miguel Villasuso

1993 "Influence of the Holbox Fracture Zone on the Karst Geomorphology and Hydrogeology of Northern Quintana Roo, Yucatan Peninsula, Mexico," in Barry F. Beck, ed., Applied Karst Geology. Rotterdam, Netherlands: A. A. Balkema, 181-188.

Turner, B. L., II

1978 "The Development and Demise of the Swidden Thesis of Maya Agriculture," in Peter D. Harrison and B. L. Turner II, eds., Pre-Hispanic Maya Agriculture. Albuquerque: University of New Mexico Press, 13-22.

1990 "Population Reconstruction for the Central Maya Lowlands: 1000 B.C. to A.D. 1500,' in T. Patrick Culbert and Don S. Rice, eds., Precolumbian Population History in the Maya Lowlands. Albuquerque: University of New Mexico Press, 301-324.

Turner, B. L., II, and Peter D. Harrison, editors

1983 Pulltrouser Swamp: Ancient Maya Habitat, Agriculture, and Settlement in Northern Belize. Austin: University of Texas Press.

Velázquez Morlet, Adriana, Edmundo López de la Rosa, Alejandro Pacheco Méndez, Carlos Ruiz Ulloa, and Miguel Angel Valenzuela Tovar

1991 "Algunos Comentarios sobre las Características Arquitectónicas del Noreste de Yucatán," Cuadernos de Arquitectura Mesoamericana 12: 57-63.

Vlcek, David T., Sylvia Garza de González, and Edward B. Kurjack

1978 "Contemporary Farming and Ancient Maya Settlements: Some Disconcerting Evidence," in Peter D. Harrison and B. L. Turner II, eds., Pre-Hispanic Maya Agriculture. Albuquerque: University of New Mexico Press, 211-223.

Vymazal, Jan, and Curtis J. Richardson

1995 "Species Composition, Biomass, and Nutrient Content of Periphyton in the Florida Everglades," Journal of Phycology 31: 343-354.

Webster, David

1979 Cuca, Chacchob, Dzonot Aké: Three Walled Northern Maya Centers. Occasional Papers in Anthropology 11. University Park: Pennsylvania State University.

Weidie, A. E.

1982 "Lineaments of the Yucatán Peninsula and Fractures of the Central Quintana Roo Coast: Road Log and Supplement to 1978 Guidebook" Geological Society of America Anmual Meeting Field Trip 10: 21-25.

1985 "Geology of the Yucatan Platform" in W. C. Ward, A. E. Weidie, and W. Back, eds., Geology and Hydrogeology of the Yucatan and Quaternary Geology of Northern Yucatan Peninsula. New Orleans: New Orleans Geological Society Publications, 1-12, 18-19.

West, Robert C.

1964 "The Natural Regions of Middle America," in Robert C. West, ed., Handbook of Middle American Indians 1, Natural Environment and Early Cultures. Austin: University of Texas Press, 363-383.

Wetzel, Robert G., editor

1983 Periphyton of Freshwater Ecosystems. The Hague: Dr. W. Junk Publishers.

Wilk, Richard R.

1985 "Dry Season Agriculture among the Kekchi Maya and its 
Implications for Prehistory," in Mary D. Pohl, ed., Prehistoric Lowland Maya Environment and Subsistence Economy. Papers of the Peabody Museum of Archaeology and Ethnology

Wilken, Gene C.

77. Cambridge, MA: Harvard University Press, 47-57.

1987 Good Farmers: Traditional Agricultural Resource Management in Mexico and Central America. Berkeley: University of California Press.

Wilson, Eugene M.

1980 "Physical Geography of the Yucatan Peninsula," in Edward H. Moseley and Edward D. Terry, eds., Yucatan, a World Apart. University: The University of Alabama Press, 5-40.

Winzler, Susan, and Scott L. Fedick

1995 "Ancient Maya Wells and Water Resources of the Yalahau Region," in Scott L. Fedick and Karl A. Taube, eds., The View From Yalabau: 1993 Archaeological Investigations in Northern Quintana Roo, Mexico. Latin American Studies Program, Field Report Series 2. Riverside: University of California, 101-113. 